\title{
Numerical simulations of local circulations and pollution transport over Reunion Island
}

\author{
D. Lesouëf ${ }^{1}$, F. Gheusi ${ }^{2}$, R. Delmas ${ }^{1}$, and J. Escobar ${ }^{2}$ \\ ${ }^{1}$ Laboratoire de l'Atmosphère et des Cyclones, Université de La Reunion, CNRS/INSU UMR8105, La Réunion, France \\ ${ }^{2}$ Laboratoire d'Aérologie, Université Toulouse III, CNRS/INSU UMR5560, Toulouse, France
}

Received: 24 May 2010 - Revised: 15 December 2010 - Accepted: 16 December 2010 - Published: 6 January 2011

\begin{abstract}
A series of high-resolution $(1 \mathrm{~km})$ numerical simulations with a limited-area numerical model has been performed over Reunion Island. In the dynamical context of a regular maritime flow perturbed by a major topographic obstacle such as Reunion Island, the objectives are to identify the main atmospheric circulations at local-scale over the island and to improve the understanding of local-scale transport and dispersion of pollutants emitted from local sources. To investigate the effects of topography and land surface heating on low-level flows over the island, simulations representative of austral winter were performed in idealized conditions keeping the radiative forcing plus a background eastsouth-easterly synoptic flux of varying strengths, typical of the prevailing trade-wind conditions.

The numerical experiments show mainly that flow splitting of the trade-wind occurs around the island, with enhanced winds blowing along the coast lines parallel to the synoptic flux, due to the lateral constriction of the flow by the island and resulting Venturi effect. Blocking occurs on the island side facing the trade-wind. The north-western area on the leeside is screened from the trade-wind by high mountains, and this enables the development of diurnal thermallyinduced circulations, combining downslope and land-breeze at night, and upslope and sea breeze at daytime. Flow splitting is modulated by radiative convergence toward the island at daytime, and divergence from the island at night. Stronger winds than the large-scale trade-wind occur along the coast at daytime (Venturi effect), whereas at night, the trade-wind flow is pushed few kilometres offshore by divergence of cooled air from the land.
\end{abstract}

At night, the trade-wind flow is pushed few kilometres offshore by divergence of cooled air from the land.

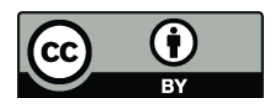

Correspondence to: D. Lesouëf (dorothee.lesouef@univ-reunion.fr)
Consequently, a number of processes of pollution transport and dispersion have been identified. Vortices in the wake of the island were found to cause counterflow circulation and trapping of polluted air masses near the north-western coast. These air masses may in turn be sucked by anabatic wind systems during daytime (upslope and sea breezes) in the cirques and up to the summits of the island, and especially to Piton Maïdo $(2200 \mathrm{~m})$ where a new observatory of the Indian Ocean background atmosphere is being built. A "cap effect" above the mountains downstream from the volcano (to the south-east of the island), and especially above Piton Maïdo, might occur in case of development of inland and upslope breezes on the west coast. In this case, air pumped from lower layers may protect the observatory from the volcanic plume forced to pass over a "cap" of low-level air clean of volcanic emissions.

Keywords. Meteorology and atmospheric dynamics (General or miscellaneous)

\section{Introduction}

A series of high-resolution numerical simulations with a limited-area numerical model has been performed over Reunion Island with the aim of better understanding of localscale transport and dispersion of pollutants emitted from local sources. This numerical study has been partly conducted in the perspective of the new atmospheric research station of Piton Maïdo, a summit at $2200 \mathrm{~m}$ above sea level on the west coast of the island (see location "MAI" in Fig. 1), in the frame of the developing Atmospheric Physics Observatory of La Reunion (Observatoire de Physique de l'Atmosphère de la Réunion, OPAR as French acronym, http://opar.univ-reunion.fr). The future Piton Maïdo station aims to be a reference observatory for atmosphere monitoring in the Southern Hemisphere, and a key component of the

Published by Copernicus Publications on behalf of the European Geosciences Union. 
observation system GAW (Global Atmosphere Watch) for the global atmosphere change studies driven by the World Meteorological Organization (Baray et al., 2006). Among the scientific questions raised in this paper, it is examined to what extent local orographic perturbations of the synoptic wind and local wind systems are responsible for vertical transport of air pollutants originating from the island boundary layer, and could affect ground-based measurements at the future Piton Maïdo observatory devoted to the monitoring of background atmospheric composition (greenhouse gases and aerosols).

Beyond this concern is also monitoring and control of local air-quality at Reunion Island, but also more generally in other mountainous tropical islands. The meso-scale model ALADIN-Reunion, which provides operational meteorological forecasts for the south-western Indian Ocean, is currently performed at a horizontal resolution around $10 \mathrm{~km}$, which is too coarse to represent atmospheric processes below the global scale of Reunion Island $(50 \mathrm{~km} \times 70 \mathrm{~km})$. Though, if one wants to establish connections between local pollution sources and receptors, it is fundamental to accurately simulate the atmospheric flow below the global scale, including circulations in the main canyons and cirques of the island, as well as radiative effects on the slopes.

The main sources of air pollution over this small but highly inhabited island (over 800000 inhabitants) are thermal power plants, sugar factories, the main urban cores and intense road traffic all around the island. Eruptions of the Piton de la Fournaise volcano in the south-east part of the island are also sporadic but major sources of pollution. For instance, during the April-May 2007 eruption, the air-quality standard for ecosystem and human health protection was exceeded for sulfur dioxide at several inhabited locations in the north-west part of the island (opposite from the location of the eruption). Some other locations closer to the volcano were surprisingly less affected. Therefore, to understand such observations, it is needed to investigate local air-pollution transport patterns with a high resolution model.

Reunion Island is a major topographic obstacle (above $3000 \mathrm{~m}$ ) located in the influence of very regular eastsouth-easterly trade-wind. Stable flows perturbed by threedimensional obstacles are a classic topic in fluid mechanics and meteorology (Brighton, 1978). The presence of an isolated island disturbs the uniform background flow and produces various flow patterns, such as blocking on the windward side, Venturi effect on the laterals, and vortices in the lee. The flow may go above or around the island depending on vertical static stability, maximum obstacle elevation and speed of the impinging flow. The relevant parameter to distinguish flow regimes is the Froude number, which is proportional to the ratio of kinetic to potential energy $(F r=U / N h$ where $U$ is the mean upstream flow speed, $N$ is the BruntVäisälä frequency and $h$ the height of the obstacle). Values well below unity are characteristic of the "flow-around" regime, i.e. blocking on the windward side of the island, and flow separation around the obstacle. Theoretical considerations of flow regimes in some experiments can be found in the paper of Brighton (1977), which is a qualitative study of three-dimensional flow patterns at low Froude numbers (e.g. less than unity). The variety of phenomena induced by the atmospheric flow past single isolated islands has been documented by numerous specific studies using satellite and aerial observations, as well as numerical techniques. For instance, field campaigns based on data collected during the 1985 Joint Hawaii Warm Rain Project and the 1990 Hawaiian Rainband Project (Austin et al., 1996; Rasmussen et al., 1989; Smolarkievicz et al., 1988) show that gravity waves, rainbands and deep convection may form as result of the trade-wind flow impinging on a tropical island. Besides, when wind flows around an island, a wind wake develops on the lee side. The wind intensity is lessened closed to the obstacle due to island shielding and large wind-stress curl occurs in the wake. There are also some documentations of the formation of vortex streets in the wake of Madeira and the Canary Islands (Chopra and Hubert, 1965; Zimmermann, 1969; Moll, 1971). Smith and Grubisic (1993) utilized observations collected during the Hawaiian Rainband Project to analyze the flow in the wake of the Big Island of Hawaii and found counter-rotating lee vortices.

Thermally driven circulations in the atmosphere are generated by local thermal contrast between land and sea, or between heated or cooled air adjacent to mountain slopes, and free air at the same altitude but uninfluenced by the surface. Over islands characterized by steep topography, the daytime upslope and sea-breezes, or the nighttime downslope and land-breezes combine at coastal locations, and their respective effects are difficult to discriminate. Descriptions of thermally driven circulations for tropical islands can be identified in the meteorological literature, regarding particularly the Hawaiian Islands. The combined effects of the sea (land) breeze, mountain (valley) breeze and the tradewind have been highlighted in the past mostly by observational studies of the island-induced wind regimes (Leopold, 1949; Eber, 1957; Mendonca, 1969; Garett, 1980; Schroeder, 1981). The thermally driven daytime upslope/sea-breeze flow and nighttime downslope/land-breeze flow (Schroeder et al., 1977; Feng and Chen, 1998) become significant especially in areas with weak surface winds due to island blocking (Smolarkiewicz et al., 1998). These diurnal circulations can develop cloud and precipitation patterns (Chen and Wang, 1994).

The objective of the present study is not to contribute to an already considerable amount of knowledge on local meteorology on islands, but rather to investigate the question of local-scale transport and dispersion of pollutants emitted from local sources in the context of a quasi-stationary and uniform maritime flow (the east-south-easterly trade-wind in our context) perturbed by a major topographic obstacle such as Reunion Island. Few studies have investigated this question until now. To our knowledge, we are only able to 
mention the major photochemistry experiments MLOPEX I and II conducted at the Mauna Loa Observatory (MLO) on the island of Hawaii. A comprehensive set of measurements of photochemically-related trace gases, radical species, and photolysis rates was deployed to characterize photochemistry at synoptic scale and transport processes in the remote free troposphere. Hahn et al. (1992) discussed the influence of local meteorology on Hawaii in order to aid the interpretation of the photochemical observations performed during the experiments. Their finding is that atmosphere composition sampled at MLO is mainly modulated by alternating upslope/downslope (day/night) thermally-induced winds. Under upslope conditions, low-level air masses sampled at MLO are characterized by high moisture, low ozone levels, and some contribution of island emissions (e.g. CO, NMHC) (Atlas and Ridley, 1996). However these studies, mainly based on in-situ observations at MLO, did not investigate the local transport mechanisms in themselves. The question of pollution transport to inhabited locations of the island was also out of their scope.

Beside the island of Hawaii, numerous studies reporting atmospheric composition measurements have been carried out at numerous continental high-altitude observatories (typically above $2000 \mathrm{~m}$ ) in the world: Niwot Ridge in the Colorado mountains (Fehsenfeld, 1983), in the southern Appalachian mountains (Zaveri et al., 1995), at the high-alpine research station Jungfraujoch in Switzerland (Zellweger et al., 2000), Mt. Fuji in Japan (Tsutsumi and Matsueda, 2000), Mt. Cimone in Italia (Bonasoni et al., 2000), Mt. Abu in India (Naja et al., 2003), Pic du Midi in the Pyrenees (Chevalier et al., 2007). A common concern in these studies is the influence of surface emissions and the atmospheric boundary layer on ambient meteorology and chemistry at the stations. They emphasized various dynamical processes responsible for vertical transport of air pollutants originating from the lowland boundary layer, and contributing to the thermal pumping of the low-level atmospheric layers and vertical mixing over the mountains (high turbulence owing to the terrain roughness, thermally induced circulations, favored shallow and deep convection and direct orographic lifting of synoptic flows). Moreover, among the above-mentioned studies, some of them highlighted different diurnal behaviors of surface ozone concentrations at low-elevation plain and valley sites on one side, and at high-elevation mountainous locations on the other side. At low elevations, ozone follows a typical solar radiation cycle with high concentrations during the day associated with locally generated photochemical production and important vertical mixing, and low nocturnal values due to chemical loss by nitrous oxide and deposition process in the stable nocturnal atmosphere. Observations at high-elevation ground stations, like at Mauna Loa, often exhibit a reversed diurnal ozone cycle: minimum values during the day are mainly due to the local topographically-induced wind systems bringing upwards ozone-depleted air from the boundary layer to the top of the mountain.

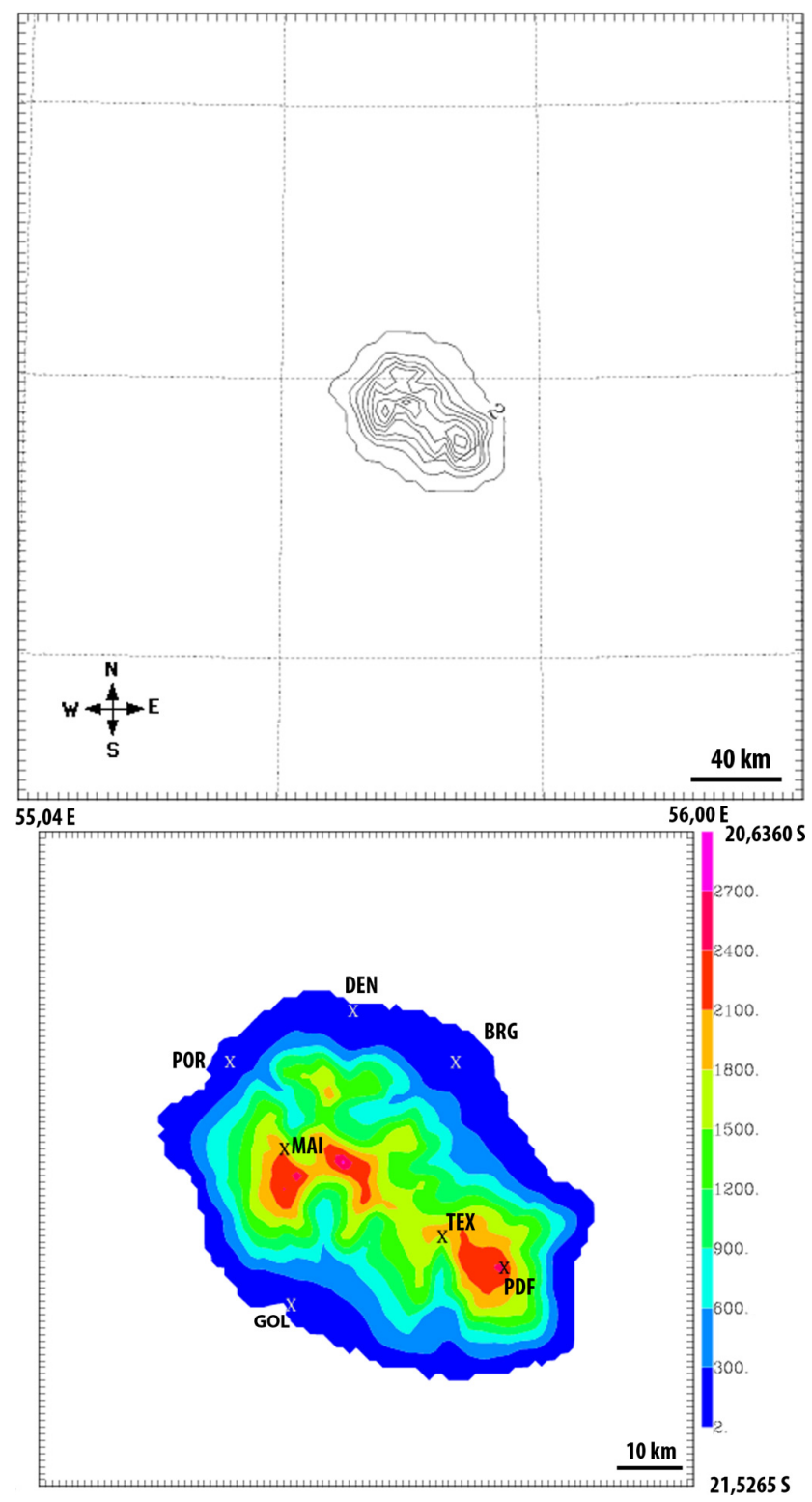

Fig. 1. The used nested model domains (horizontal resolutions: $4 \mathrm{~km}$ (top), $1 \mathrm{~km}$ (bottom)). The place names used in this paper are indicated on the bottom panel. The colorscale represents the elevation of the terrain in $\mathrm{m}$ (from MesoNH model).

The purposes of this paper are to (i) identify atmospheric circulations at the scale of the island and (ii) to study to what extent they could affect the atmospheric composition measured at Piton Maïdo and in the inhabited areas of the island. Section 2 summarizes needed elements on Reunion Island's geography and on specific meteorological features. The idealized numerical strategy and the model set-up are detailed in Sect. 3. The flow patterns at the scale of the island induced by impinging trade-wind flows of various strengths are analyzed in Sect. 4.1, as well as the modulations due to land surface heating and cooling. The influence of the atmospheric 


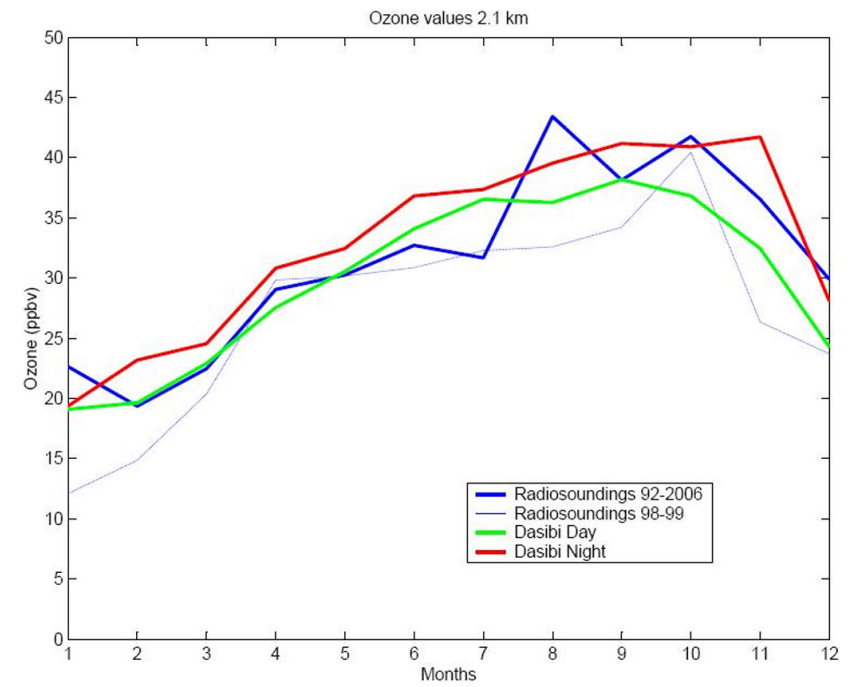

Fig. 2. Seasonal evolution of ozone concentration at Piton Textor (TEX, see Fig. 1) at $2100 \mathrm{~m}$ altitude in the South East of Reunion Island during daytime (green curve) and night time (red curve), from October 1998 to October 1999, and average value of ozone concentration at the same altitude from radiosoundings (average monthly averaged data from 1992 to 2006, and monthly data from October 1998 to October 1999, blue curves). Monthly means of ground-based ozone have been calculated separating nighttime (from 22:00 h to 07:00 h, local time) and daytime (from 08:00 h to 20:00 h, local time) measurements. Data provided by F. Posny, J. M. Metzger and C. Bhugwant.

boundary layer and the transport of pollutant passive tracers to Piton Maïdo will be discussed respectively in Sects. 4.1 and 4.2. Section 5 summarizes the conclusions and presents the research perspectives.

\section{Environmental context}

Reunion Island $\left(21^{\circ} 07^{\prime} \mathrm{S}, 55^{\circ} 32^{\prime} \mathrm{E}\right)$ is an isolated mountainous island located in the Indian Ocean, about $800 \mathrm{~km}$ east of Madagascar. Reunion's climatic context is typical of the tropical ocean. The island is most of the time under the influence of the east-south-easterly trade-wind. This wind prevails throughout the year but strengthens during austral winter from May to November (Baldy et al., 1996). A wind inversion resulting from the descending branch of the Hadley cell circulation is the main characteristic of the wind vertical distribution over Reunion: low-level easterlies are opposite to upper-level westerlies. This inversion occurs at around $4000 \mathrm{~m}$ above sea level (Taupin et al., 1999) and is a persistent feature of the trade-wind pattern. It coincides with a temperature inversion (due to synoptic subsidence capping convection in the low layers over the ocean) and behaves as a barrier for the development of clouds (Hastenrath, 1991).

Reunion Island's complex topography is composed of deep canyons, cirques, ravines and ridges, with two main massives dominated by two major summits: Piton des Neiges (3070 $\mathrm{m}$ a.s.1.) and Piton de la Fournaise (2632 $\mathrm{m}$ a.s.1.). The prevailing humid trade-wind flow impinging on the complex topography causes large spatial variations in local weather ranging from extremely wet and rainy conditions on the windward side to much drier conditions on the leeward side. In the lee of the island, corresponding to regions of weak winds, the surface flow fluctuates diurnally, thermally controlled by temperature contrasts between land and sea on the one hand, and due to heated/cooled mountain surface on the other hand.

Piton Maïdo, where the future atmospheric observatory is going to be established, is a high-altitude site situated on the north-west coast at $2200 \mathrm{~m}$ above sea level (location "MAI" in Fig. 1). No in-situ composition measurements have been yet conducted there, but as the Mauna Loa observatory, it might be under the influence of air vertical motions inducing chemical exchanges between the atmospheric boundary layer and the free troposphere. Ground-based ozone measurements by a UV photometer Dasibi 1008 RS were performed during one year at an other elevated site in Reunion Island (Piton Textor $2150 \mathrm{~m}$ a.s.1., in the South East; see location "TEX" in Fig. 1) (Bhugwant et al., 2001). These observations also indicated an ozone cycle with diurnal minimum and nighttime recovery (Fig. 2). Monthly means of ground-based ozone have been calculated, separating nighttime (from 22:00 h to 07:00 h) and daytime $(08: 00 \mathrm{~h}$ to 20:00 h). They are compared in Fig. 2: ozone values observed during the night are greater than those observed during the day by about $5 \mathrm{ppb}$. This pattern - typical of mountainous observatories - is basically governed by daytime upward transport of air which, in the background atmosphere over the ocean, is poorer in ozone in the lower levels than at the altitude of the station, as revealed by a climatology of ozone balloon-soundings launched from the island (Fig. 3). As at Piton Textor, one can expect that the composition of the ambient atmosphere at Piton Maïdo is intermittently influenced by ozone-depleted air or atmospheric constituents transported from lower levels.

The Piton de La Fournaise volcano (2632 $\mathrm{m}$ a.s.1.) is a typical basaltic shield volcano located in the southeastern part of the island and is one of the world's most active and productive volcanoes. Bhugwant et al. (2002) showed that it can be responsible for $\mathrm{SO}_{2}$ pollution events observed over a large part of the island. The plumes of gases released during eruptions can endanger health and environment. During the major eruption in April 2007, high concentrations of $\mathrm{SO}_{2}$ were recorded in the southern part of the island close to the eruption, but also in the south-western and north-western parts, which are densely populated and where the number of hospitalizations for asthma increased (Viane et al., 2009). The plumes of gases might also affect the chemical measurements recorded at Piton Maïdo. This question is addressed in this study. 

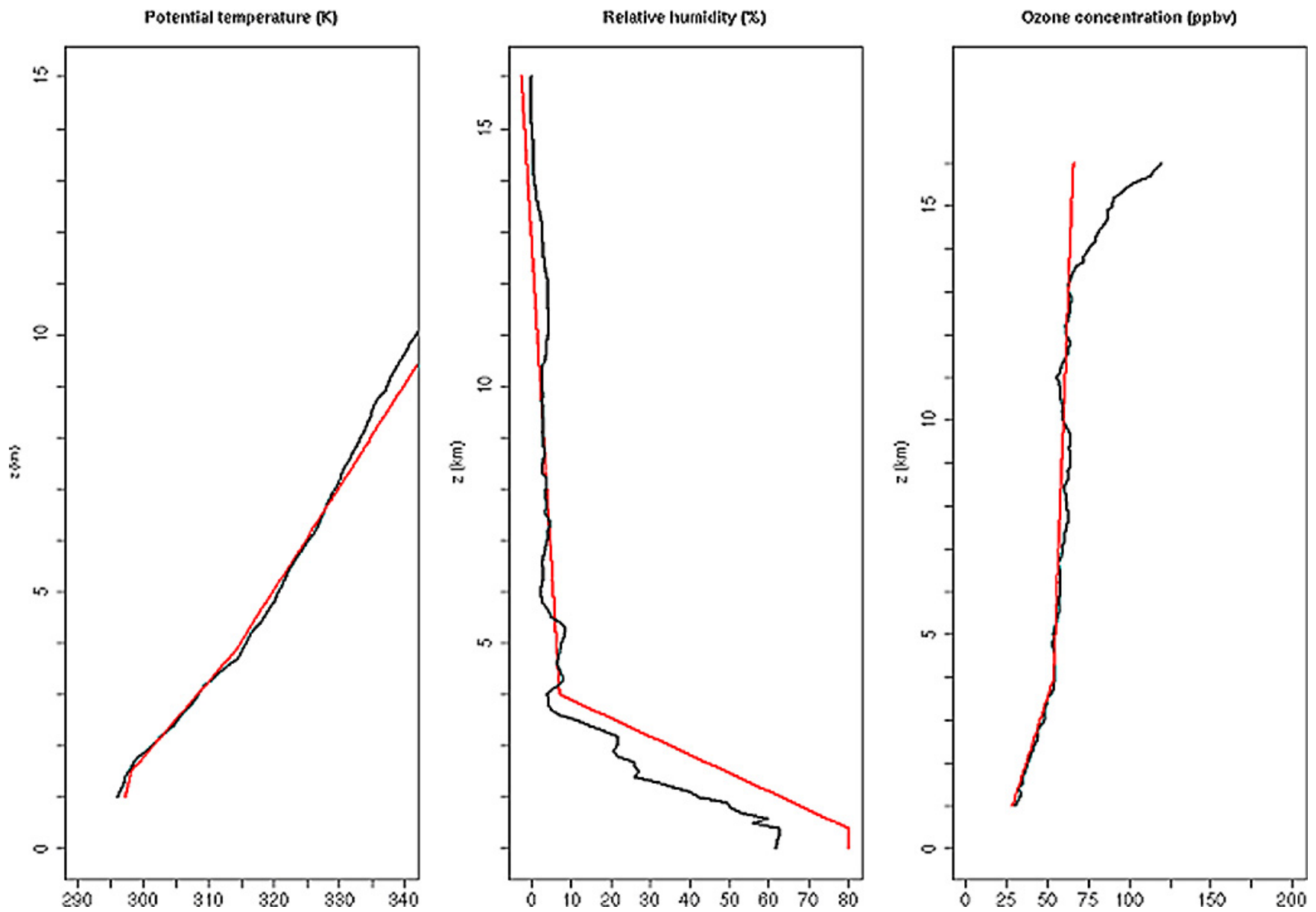

Fig. 3. Mean vertical profiles of potential temperature (K), relative humidity (\%) and $\mathrm{O}_{3}$ (ppbv) during austral winter (black curves) and modelisation (red lines).

\section{Description of the numerical experiments}

Performing studies in idealized conditions allows to isolate the most important mechanisms governing real atmospheric phenomena. Here, we intended to investigate the effects of topography and land surface heating/cooling on low-level flows, while avoiding the complexity of real-case situations. Thus, only the major elements of the physical problem were kept in an idealized configuration, namely (i) the topography and surface characteristics of the island, (ii) a steady uniform background flow representative of large scale tradewind, and (iii) solar radiation.

The physical configuration of an isolated island impinged by the trade-wind is particularly well suited for simulations in idealized mode, because of the steadiness and the quasi uniformity of the background synoptic flow at the scale of the model domain, the absence of relief at its boundaries, and the quasi constant sea surface temperature. This real physical configuration is quite simple, and due to this the presented simulations, although idealized, are expected to have a good degree of representativeness of typical atmospheric condi- tions prevailing on Reunion Island. Further, a number of identified transport mechanisms might be easily transposed to other tropical islands.

In this work, we used the three-dimensional, nonhydrostatic, limited-area research model, MesoNH. This has been developed in a joint effort by CNRM (National Center of Meteorological Research, MétéoFrance) and LA (Laboratory of Aerology, Toulouse University). It is based on the Lipps and Hemler (1982) anelastic system and is able to simulate atmospheric flows ranging from large turbulent eddies to the synoptic scale. A detailed description of the model dynamical core can be found in previous publications (Lafore et al., 1998; Stein et al., 2000). It is appropriate for dynamical studies over steep topography and is equipped with a full set of parameterizations allowing to represent accurately various physical processes.

To suitably capture flow patterns at the scale of the main topographic features of the island, high resolution was required but in the same time, the model lateral boundaries had to be sufficiently far from the island so that the impinging uniform flow was not perturbed by the island at the model 
Table 1. Model nesting configuration for MesoNH.

\begin{tabular}{cccclc}
\hline Domain nested & $\begin{array}{c}\text { Horizontal } \\
\text { grid points }\end{array}$ & $\begin{array}{c}\text { Horizontal } \\
\text { resolution }(\mathrm{m})\end{array}$ & $\begin{array}{c}\text { Domain } \\
\text { extension }\left(\mathrm{km}^{2}\right)\end{array}$ & $\begin{array}{l}\text { Stretched } \\
\text { vertical grid }\end{array}$ & $\begin{array}{c}\text { Time step } \\
(\mathrm{s})\end{array}$ \\
\hline 1 & $80 \times 80$ & $4000 \times 4000$ & $320 \times 320$ & $\begin{array}{l}72 \text { levels } \\
1 \text { st level: } 40 \mathrm{~m} \\
\text { near model top }(27 \mathrm{~km}):\end{array}$ \\
& & & $600 \mathrm{~m}$ & 5 \\
2 & $100 \times 100$ & $1000 \times 1000$ & $100 \times 100$ & & 5 \\
\hline
\end{tabular}

boundaries upstream of the obstacle. Therefore the simulations were run using two nested models with different resolutions and geographical covers. The outer domain covers $320 \times 320 \mathrm{~km}^{2}$ with $80 \times 80$ grid points, while the inner domain covers $100 \times 100 \mathrm{~km}^{2}$ with $100 \times 100$ grid points. Both models are centered at $21.1^{\circ} \mathrm{S}$ and $55.5^{\circ} \mathrm{E}$. One-way gridnesting (i.e. the outer low-resolution model driving the lateral boundary conditions of the inner high-resolution model, but without retroaction of the latter on the former) was sufficient for our study since we were only interested in finescale processes in the inner high-resolution model ${ }^{1}$. The two nested domains had horizontal resolutions of $4 \mathrm{~km}$ and $1 \mathrm{~km}$, respectively (Fig. 1). In previous studies, the $1 \mathrm{~km}$ resolution appeared to be sufficient to well simulate thermally-induced circulations and thermal pumping over extremely steep and complex terrain (De Wekker et al., 2004; Gheusi et al., 2008). Another point concerning the resolution is its smoothing effect and the resulting effective height of the island. The two main massives of the island peak at 2770 and $2330 \mathrm{~m}$ a.s.1. in the model, compared to 3070 and $2632 \mathrm{~m}$ in reality. Thus, the differences are small and the overall flow regime over the island cannot be affected by excessive smoothing.

The common vertical grid includes 72 terrain-following levels up to $27 \mathrm{~km}$ in Gal-Chen and Sommerville (1975) vertical coordinate. Vertical stretching of the model levels allowed increased resolution near the soil to obtain a finer description of the atmospheric boundary layer. Grid spacing varied from $40 \mathrm{~m}$ near the ground to $600 \mathrm{~m}$ in the highest levels. The detailed features for each model subdomain are summarized in Table 1. Some details on the lateral boundary conditions for each model is given below in the text.

\footnotetext{
${ }^{1}$ In a sensitivity test comparing the one-way and two-way approaches, significant differences in the finer models might arise only if the flow would cross out the limit of the fine-model domain, then again in. Only in this case the fine model would be influenced at its boundary by fields from the coarse model which would be different in the one-way and two-way simulations. As the presented figures show, this almost never occurs in our simulations.
}

Simulations described in this paper were performed with the following set of physical parameterizations, successfully used in many previous studies with MesoNH at high resolution over complex mountainous terrain (e.g. Asencio et al., 2003; Martinez et al., 2010; Richard et al., 2011; and many other publications listed on http://mesonh. aero.obs-mip.fr/mesonh/). Subgrid turbulence is parameterized with a one-dimensional, 1.5-order closure scheme, involving a prognostic equation for turbulent kinetic energy (Cuxart et al., 2000) and using the Bougeault and Lacarrère (1989) mixing length. The orography was obtained from the GTOPO30 database (http://eros.usgs.gov/\#/Find_Data/ Products_and_Data_Available/gtopo30_info) and the land cover was taken from the ECOCLIMAP database (Masson et al., 2003). The surface soil and vegetation processes were simulated by the Interface Soil Biosphere Atmosphere (ISBA) model (Noilhan and Planton, 1989). The Morcrette (1991; also Mlawer et al., 1997) radiation scheme of the ECMWF treating both visible and near infra-red radiation is used to calculate the radiative fluxes and called every $1800 \mathrm{~s}$. For the warm water phases, the used microphysical scheme was of Kessler type, and a parameterization of atmospheric ice was also employed (Pinty and Jabouille, 1998). A subgrid condensation scheme was activated to account for non-resolved orographic clouds (Chaboureau and Bechtold, 2002, 2005).

The model was initialized at 00:00 UTC (04:00 LT), close in time to the nocturnal temperature minimum. The computations were carried out over a period of $48 \mathrm{~h}$. Stationary and horizontally uniform "large-scale" fields (thereafter LS fields) of wind, potential temperature and specific humidity were defined with the view to both initialize the model and force the lateral boundary conditions of the outermost model during the run. The lateral boundary conditions used for the outermost model were open and externally forced by the LS fields. As for many usual applications of MesoNH, our configuration required simultaneously to let the shortscale waves out of the model domain with minimum reflection at the boundaries, and the LS fields get into the model by boundary forcing. This was achieved through the use of a mixed radiation/relaxation method described in Lafore et al. (1998). 

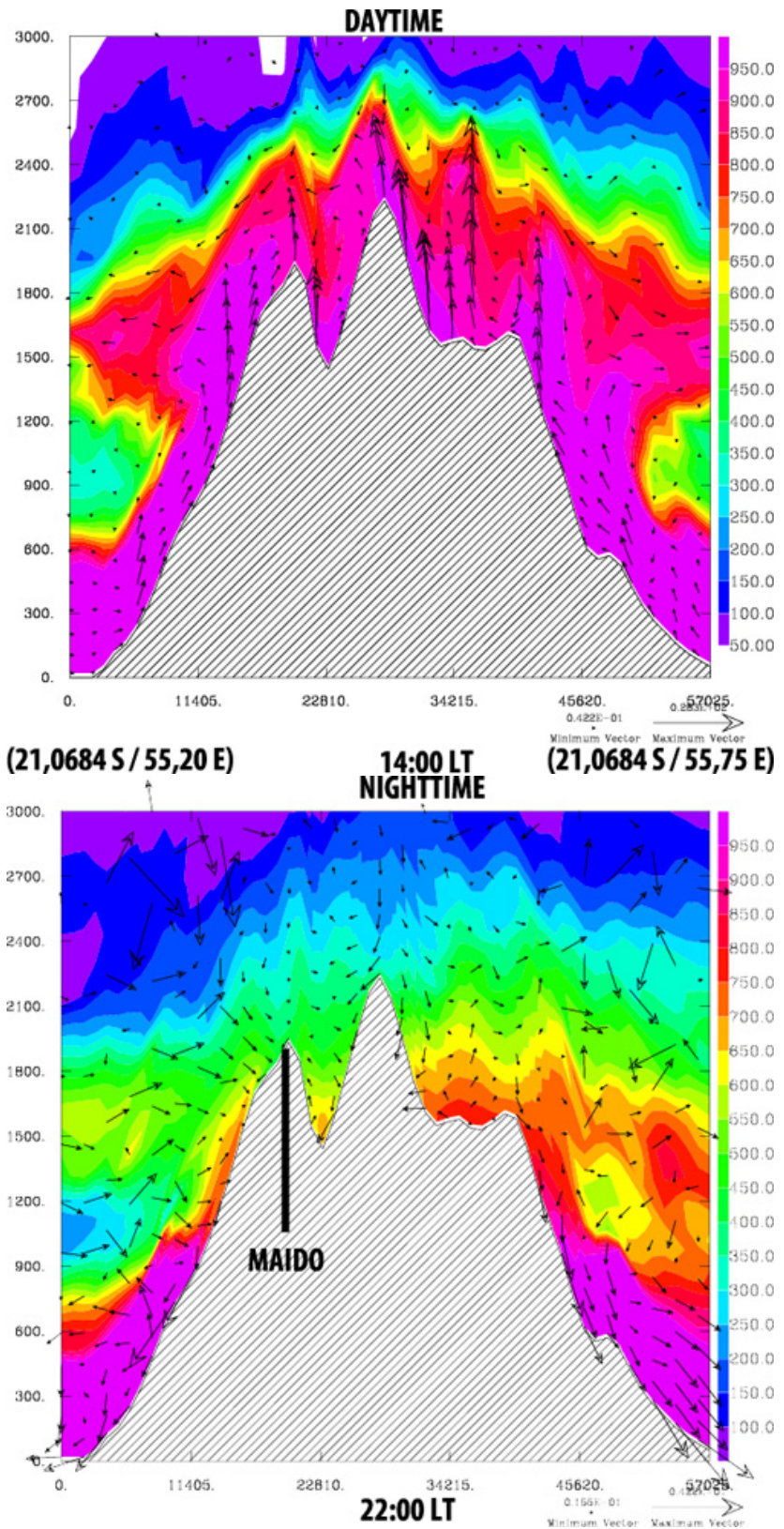

Fig. 4. Simulation ALIZ0: W-E vertical cross section of the island (indicated in Fig. 9, top) showing the ABL tracer concentration (per mil of the concentration in the "ABL", see Sect. 3 and Fig. 5) at 14:00 LT (top) and 00:00 LT (bottom).

These LS fields were designed to be representative of the trade-wind layer of the troposphere in austral winter. For this goal, idealized profiles of potential temperature and relative humidity have been inspired by a climatology (Fig. 3) based on balloon soundings in the frame of the SHADOZ network (Thompson et al., 2003). The balloon soundings used for the climatology have been performed in austral winter between 1992 and 1997 at Gillot airport $\left(21.06^{\circ} \mathrm{S}, 55.48^{\circ} \mathrm{E}\right)$ in the North of the island using Vaisala radiosondes and EnSci Z \&

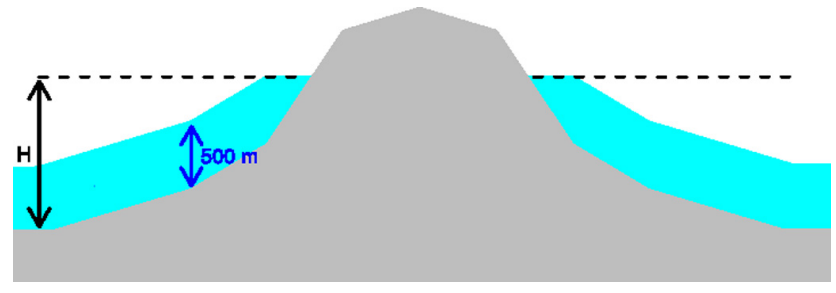

Fig. 5. Initialization of the ABL passive tracer: the blue layer is used for this purpose. It is defined as a $500 \mathrm{~m}$-deep terrain following layer, but limited at a ceiling altitude $H=1000 \mathrm{~m}$. The tracer was initialized to the arbitrary value 1000 in this blue layer, but zero above. During the model run, the tracer is refreshed at each timestep to 1000 in the blue layer, but outside it is freely advected and diffused by the model dynamics.

Table 2. Main characteristics of the numerical experiments.

\begin{tabular}{lccc}
\hline & ALIZ0 & ALIZ5 & ALIZ10 \\
\hline Trade-wind direction & $/$ & ESE & ESE \\
Trade-wind strength & $0 \mathrm{~m} \mathrm{~s}^{-1}$ & $5 \mathrm{~m} \mathrm{~s}^{-1}$ & $10 \mathrm{~m} \mathrm{~s}^{-1}$ \\
Radiative forcing & YES & YES & YES \\
\hline
\end{tabular}

SPC 6A ozonesondes. The mean balloon profiles were then simplified into four layers with constant gradients of potential temperature and relative humidity (Fig. 3). These idealized profiles were finally used by the model as LS fields. The LS wind was prescribed horizontally and vertically uniform and constant in time, blowing from east-south-east. Three different numerical experiments were carried out with background synoptic flow of 0,5 and $10 \mathrm{~m} \mathrm{~s}^{-1}$. Hereafter the simulations will be referred to as ALIZ0, ALIZ5 and ALIZ10, respectively. The trade-wind temperature inversion plays a crucial role in controlling vertical motions in the tropical troposphere. It acts as a lid which effectively limits convection below $4000 \mathrm{~m}$ (Taupin et al., 1999). The trade-wind temperature inversion was maintained in the simulations by a forced subsidence of $5.10^{-3} \mathrm{~m} \mathrm{~s}^{-1}$ at $4000 \mathrm{~m}$. The characteristics of the numerical experiments are summarized in Table 2.

The experiment ALIZ0 was performed to check the ability of the model to generate thermally driven wind systems. Without background wind and under the only influence of solar radiation, ALIZ0 simulated successfully the development of upslope thermal breezes on the island and accompanying upward export over the mountains of air from the low levels during daytime, and opposite motions and transport during night (Fig. 4). At daytime, upslope breeze brings air from the boundary layer to the top of the mountain. At nighttime, downslope breeze generates a subsiding motion and produces the opposite effect. This alternating vertical transport is well illustrated by the concentration of the boundary layer tracer found near the mountain tops, which is greater 
than 800 per mil at daytime but lower than 500 at nighttime. However, the absence of synoptic wind is a very uncommon meteorological situation in this region, and thus, no further will be said about simulation ALIZ0 beyond this verification.

Various passive tracers have been released in the model in order to characterize dynamical processes in the lower atmospheric layers and the related transport of air-masses. To understand the influence of the atmospheric boundary layer (ABL), especially at Piton Maïdo, it was useful to define two passive tracers. The first one ("ABL tracer" thereafter) is initialized to 1000 per mil in the ABL ( 0 elsewhere), then forced to 1000 per mil in the ABL at every time-step and let free to diffuse above. The ABL is here modeled as a fix $500 \mathrm{~m}$-thick terrain-following layer limited at a ceiling altitude of $1000 \mathrm{~m}$ (Fig. 5). Admittedly this is an oversimplification. Nevertheless it is a simple and sufficient manner to distinguish air masses which have passed through the lowest atmospheric layers, and whose composition might have been influenced by the surface. The second passive tracer (pseudo- $\mathrm{O}_{3}$ tracer thereafter) imitates crudely the behavior of ozone, in order to study the effect of the vertical transport and redistribution of this strongly stratified field (Chevalier et al., 2007). An averaged profile of ozone mixing ratio has been established from the observations of the SHADOZ network during austral winter and enabled to initialize the pseudo- $\mathrm{O}_{3}$ tracer in the following way: its concentration is $20 \mathrm{ppbv}$ at sea level, increases by $8.5 \mathrm{ppbv} \mathrm{km}^{-1}$ up to $54 \mathrm{ppbv}$ at an altitude of $4000 \mathrm{~m}$, and then by 1 ppbv km${ }^{-1}$ above (Fig. 3). A variable component is added to the ozone concentration between the ground and the altitude of $4000 \mathrm{~m}$ to mimic the diurnal cycle of ozone production/loss, in the form of sinusoidal oscillations with maximum amplitude of $\pm 5 \mathrm{ppbv}$ at sea level and vanishing at $4000 \mathrm{~m}$ a.s.l. It is characterized by a minimum at 02:00 a.m. and a maximum at 02:00 p.m. (local time).

To describe pollution plumes over the island, several passive tracers have been emitted from local sources, which are relatively well identified at Reunion Island. Their location is also shown in Fig. 1. Pollutants are emitted only at low altitudes because human activities are concentrated along the coastline due to the steep orography of the island. The anthropogenic sources are located in Saint Denis, the main town (DEN), in Le Port (POR) where there is a thermal power plant, in Bois-Rouge (BRG) and in Le Gol (GOL) where there are sugar factories. The last tracer accounts for natural pollution caused by the eruptions of the Piton de la Fournaise (PDF) volcano in the south-east part of the island. Pollution passive tracers were released at ground level from the grid cell containing the source point. The tracer concentration at the source point is forced to an arbitrary value of 1 at every time step. The concentration far from the source thus represents a dilution ratio with respect to the concentration at the source point of emission. The set of passive tracers is summarized in Table 3.

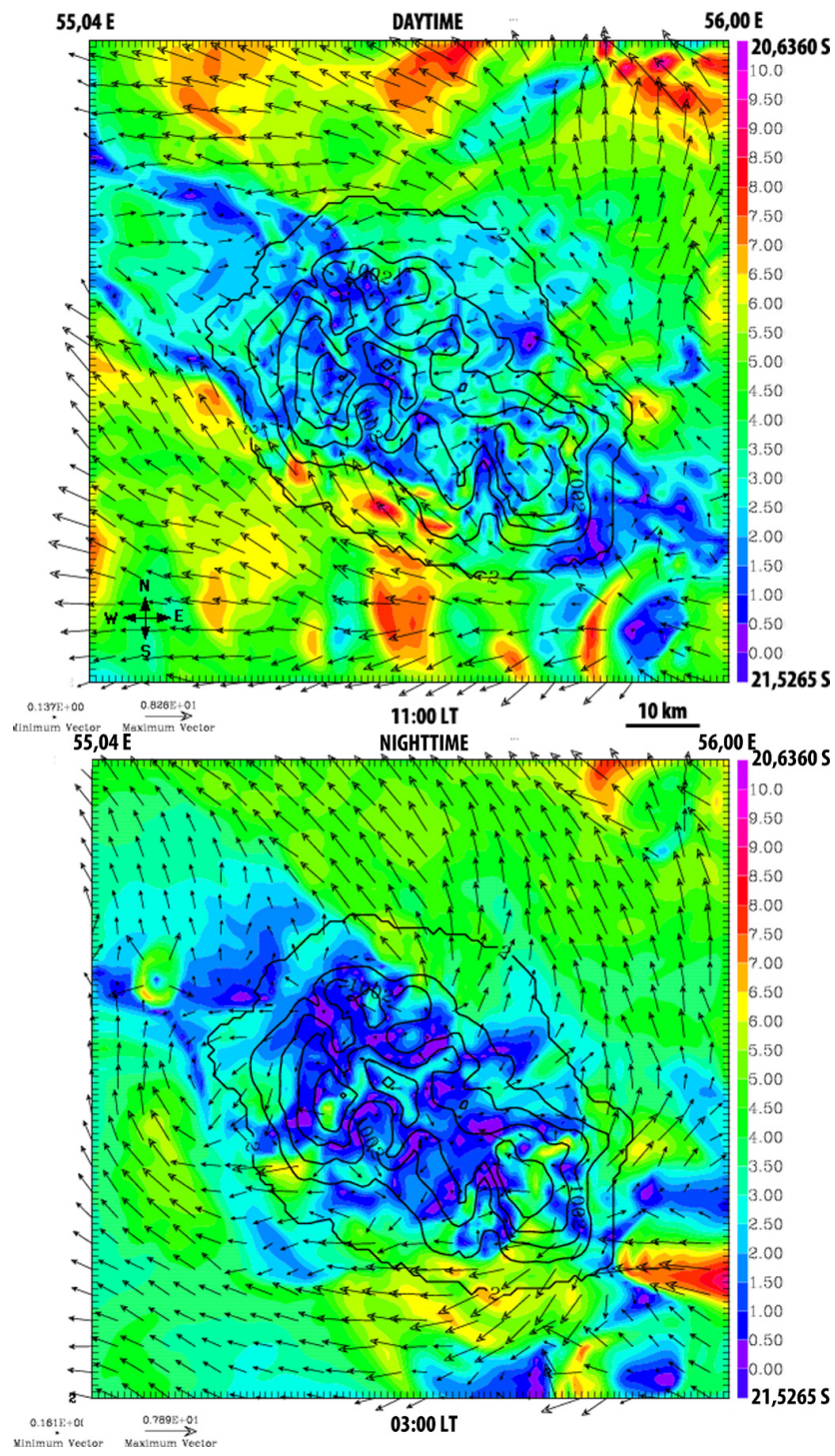

Fig. 6. Simulation ALIZ5 - wind speed (color scale) and vectors at the first model level above the ground, at 11:00 LT (top) and 03:00 LT (bottom).

\section{Simulation results}

\subsection{Flows at the island scale}

\subsubsection{Hydraulic character of the atmospheric flow around the island and thermally-induced effects}

Among the patterns generated by the trade-wind flow impinging on the island, low-level flow separation around the obstacle is an important hydraulic behavior well reproduced by the model (Fig. 6). This meteorological feature is in fact linked to the blocking of the trade-wind flow by the island due to the existence of several stable inversion layers inhibiting deep vertical motions. Reunion's elevated topography acts effectively as a substantial obstacle to the trade-wind 
Table 3. Characteristics of passive tracers used in the simulations.

\begin{tabular}{|c|c|c|}
\hline Passive tracers & Function & Motivation \\
\hline $1(\mathrm{ABL})$ & $\begin{array}{l}\text { Tracer of the atmospheric boundary layer (see } \\
\text { Fig. 4) }\end{array}$ & $\begin{array}{l}\text { Vertical exchanges between the atmospheric } \\
\text { boundary layer and the free troposphere }\end{array}$ \\
\hline $2(\mathrm{O} 3)$ & $\begin{array}{l}\text { Imitates } \mathrm{O}_{3} \text { stratification and produc- } \\
\text { tion/destruction in the } \mathrm{ABL}\end{array}$ & \\
\hline $3(\mathrm{DEN})$ & $\begin{array}{l}\text { Passive pollutant emitted from St Denis, the } \\
\text { main city }\end{array}$ & Pollution plumes from anthropogenic sources \\
\hline 4 (POR) & $\begin{array}{l}\text { Passive pollutant emitted from the power plant } \\
\text { located in Le Port }\end{array}$ & \\
\hline 5 (GOL) & $\begin{array}{l}\text { Passive pollutant emitted from the sugar fac- } \\
\text { tory, located in Le Gol }\end{array}$ & \\
\hline $6(\mathrm{BRG})$ & $\begin{array}{l}\text { Passive pollutant emitted from the sugar fac- } \\
\text { tory, located in Bois-Rouge }\end{array}$ & \\
\hline 7 (PDF) & $\begin{array}{l}\text { Passive pollutant emitted from the volcano } \\
\text { Piton de la Fournaise }\end{array}$ & $\begin{array}{l}\text { Pollution plume from the volcanic natural } \\
\text { source }\end{array}$ \\
\hline
\end{tabular}

confined below the inversion usually near $4 \mathrm{~km}$ altitude, and constrained to flow around the island. This is especially the case in the lowest levels, since another lower inversion layer exists at the top of the marine boundary layer. So the tradewind flow is blocked on the windward side of the island and split in two branches (Soler, 1997). This flow regime is confirmed by low values of the Froude Number calculated with the mean Brunt-Väisälä frequency in the tradewind layer $\left(N=0.015 \mathrm{~s}^{-1}\right)$ and the characteristic height of the island $(h=2500 \mathrm{~m})$. For typical wind speeds of $5 \mathrm{~m} \mathrm{~s}^{-1}$ and $10 \mathrm{~m} \mathrm{~s}^{-1}$, the Froude numbers are 0.13 and 0.26 , respectively.

In the numerical experiment ALIZ5, at nighttime, the combination of stabilization by cooling near the surface, land breeze and downslope nocturnal drainage flows pushes offshore the trade-wind flow separation. In the daytime, the situation reverses. Figure 6 shows the streamlines of the surface wind field from ALIZ5 at 11:00 LT and 03:00 LT: the streamlines in the lower layers pass above the ground close to the coast at daytime or even penetrate inland under the influence of thermal confluence, whereas at nighttime, the streamlines are pushed offshore under the influence of thermal divergence. This feature of the trade-wind flows will be referred to as "trade breathing" hereafter. Mean wind data recorded at Pierrefonds, located in the south-west of the island, indicate increased mean wind speed in the early afternoon due to direct exposure to the trade-wind. Conversely, the flow reaches its minimum speed at nighttime when the trade-wind flow is pushed offshore (Fig. 7).

On the leeward side screened by the island, local air circulations differ. Thermally induced winds dominate the circulation (Fig. 6), whereas on the windward and lateral sides of the island, day/night alternating breeze systems are much less evident (even though thermal effects modulate the tradewind flow regime).

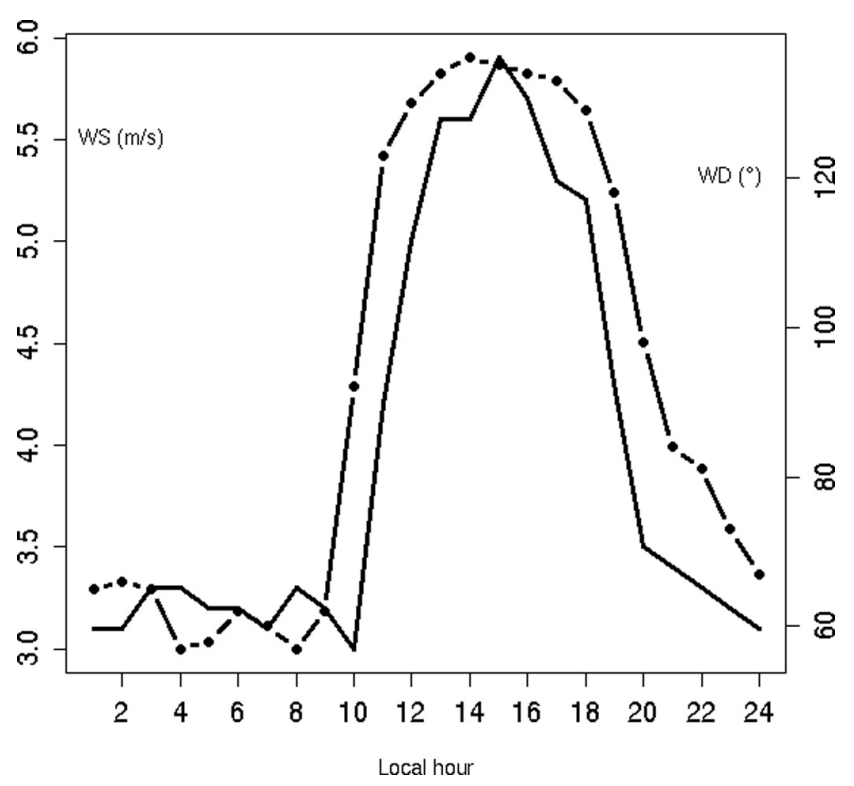

Fig. 7. Wind speed (solid line) and wind direction (dotted line) at Pierrefonds, obtained from averaged hourly observations (source: MétéoFrance) during the austral winter in 2007.

In the numerical experiment ALIZ10, the "trade breathing" is less visible. In the north-west area screened by the orography, breeze circulations still prevail. To illustrate this, the land/sea breeze regime in Le Port city located in this region was well captured by the model in qualitative agreement with observations. The wind direction given by the model was indeed compared to climatology of averaged hourly observations, during an austral winter (Fig. 8). Both observed and modeled values display a wind reversal with a decrease of the wind force around 10:00 LT and 19:00 LT. The wind coming from the west (i.e. counterflow with respect to the 


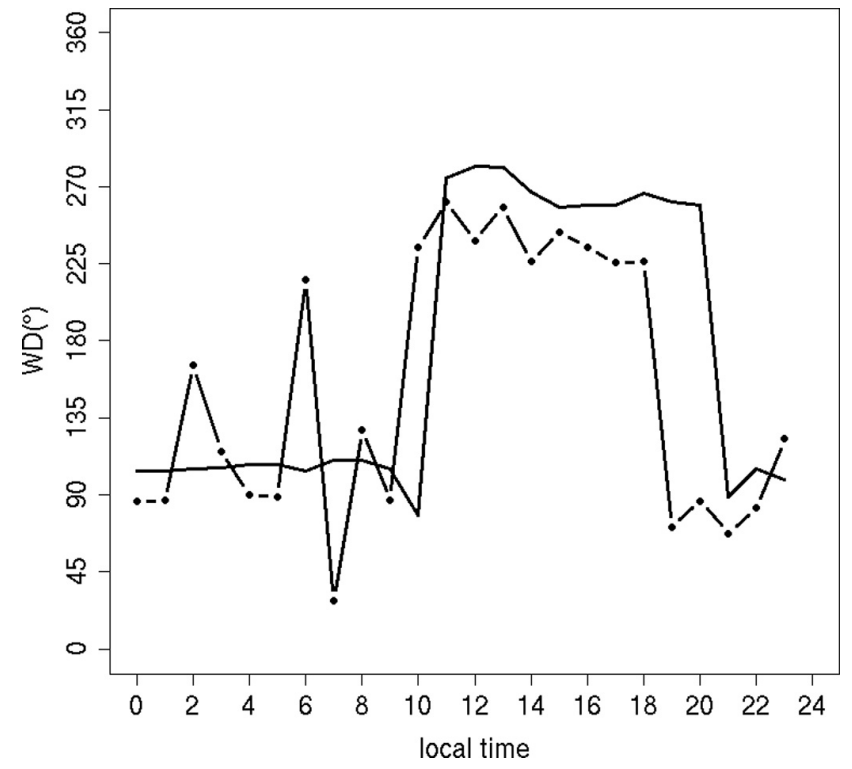

Fig. 8. Wind direction at POR (solid line: mean hourly observations over the austral winter 2007, dotted line: simulation ALIZ10).

trade-wind) during the day indicates clearly the prevalence of thermal pumping.

The trade-wind flow splitting causes at daytime the acceleration of air along the south coast, which is almost parallel to the flow. Known as the Venturi effect, the wind velocity is clearly higher in this area (Fig. 6) compared to its surroundings due to airflow constriction with the necessity of air mass conservation. Here, the similarity of the flow in the low levels with a hydraulic flow around an obstacle (e.g. a bridge pillar) is striking. This is due to the temperature inversion capping the boundary layer, and thus separating two air layers with contrasting density. To accelerate in response to the lateral constriction of the flow along the island, the flow converts gravitational potential energy into kinetic energy. As result, the top of the boundary layer lowers as the flow accelerates. This flow pattern is successfully simulated in ALIZ5, and it's well visible in Fig. 9 especially at daytime. The flow accelerates along the south coast of the island, and the related compression of the boundary layer exemplified by the altitude of the $296 \mathrm{~K}$-isentrope along the flow is well visible in the model. Conversely, Fig. 9 shows also that the blocked flow on the southeastern edge of the island corresponds to higher values of the $296 \mathrm{~K}$-isentrope altitude compared to the value far upstream.

Another feature of the flow pattern in the wake of the island is the occurrence of large swirls (e.g. in Fig. 15, top panel). Accompanying counter-flows turned out to play an important role in pollutant dispersion, as it will be shown in Sect. 4.2.

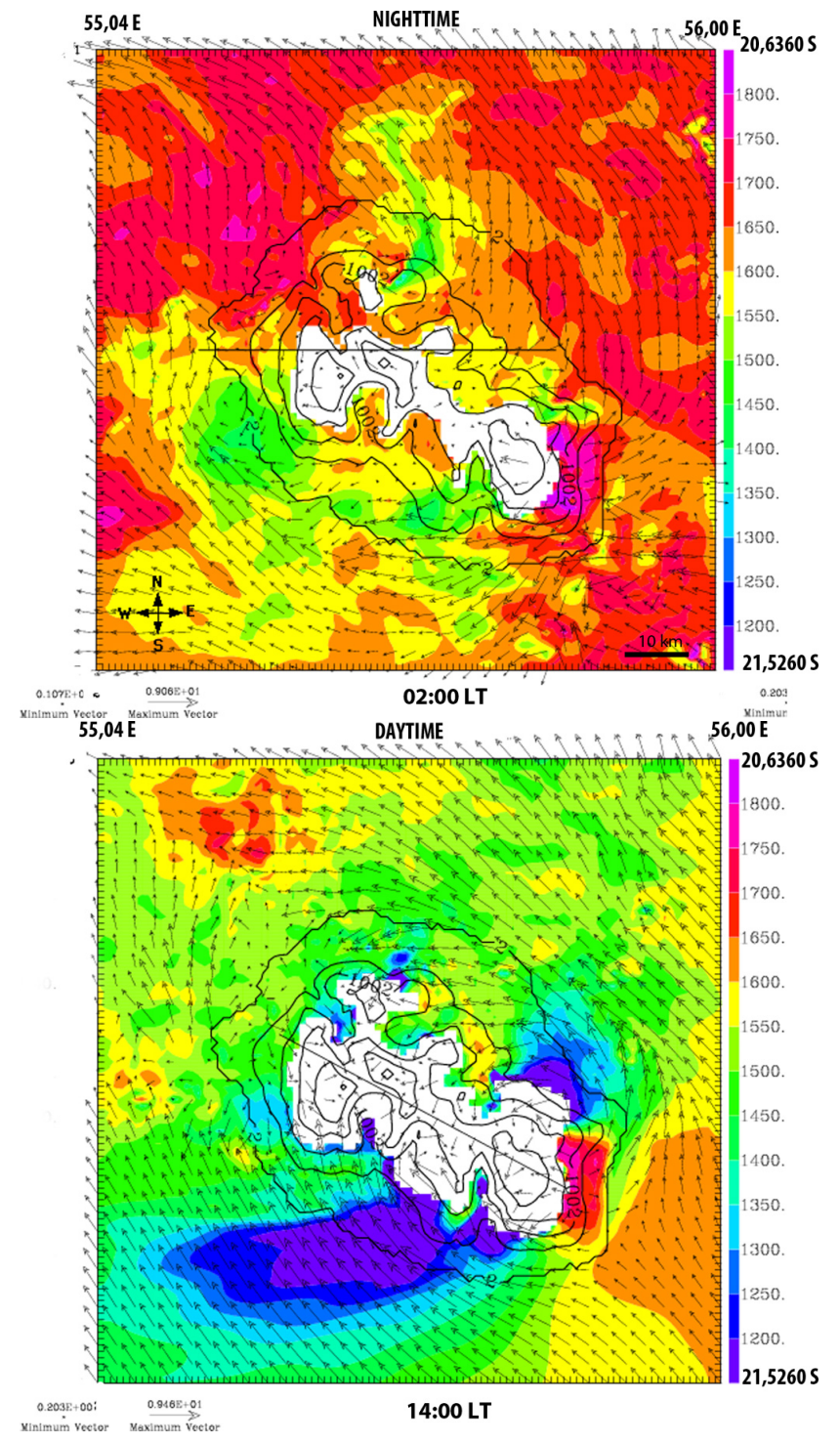

Fig. 9. Horizontal map showing the altitude of the $296 \mathrm{~K}$ isentrope (colorscale in $\mathrm{m}$ ) in the experiment ALIZ5 at 02:00 LT (top) and 14:00 LT (bottom).

\subsubsection{ABL influence at Piton Maïdo}

The ability of the model to simulate thermally-induced vertical transport (Fig. 4) and the use of a tracer of air originating from the low levels ("ABL" passive tracer described in Sect. 3) allowed, to some extent, to materialize and display the vertical exchanges between the ABL and the free troposphere.

By analogy with atmospheric measurements conducted at many high mountain stations, ground data at Piton Maïdo are expected to reveal the intermittent influence of the ABL following a diurnal cycle: local winds are expected to bring air from the ABL upwards during daytime and downwards during nighttime. Consequently, as in the background 

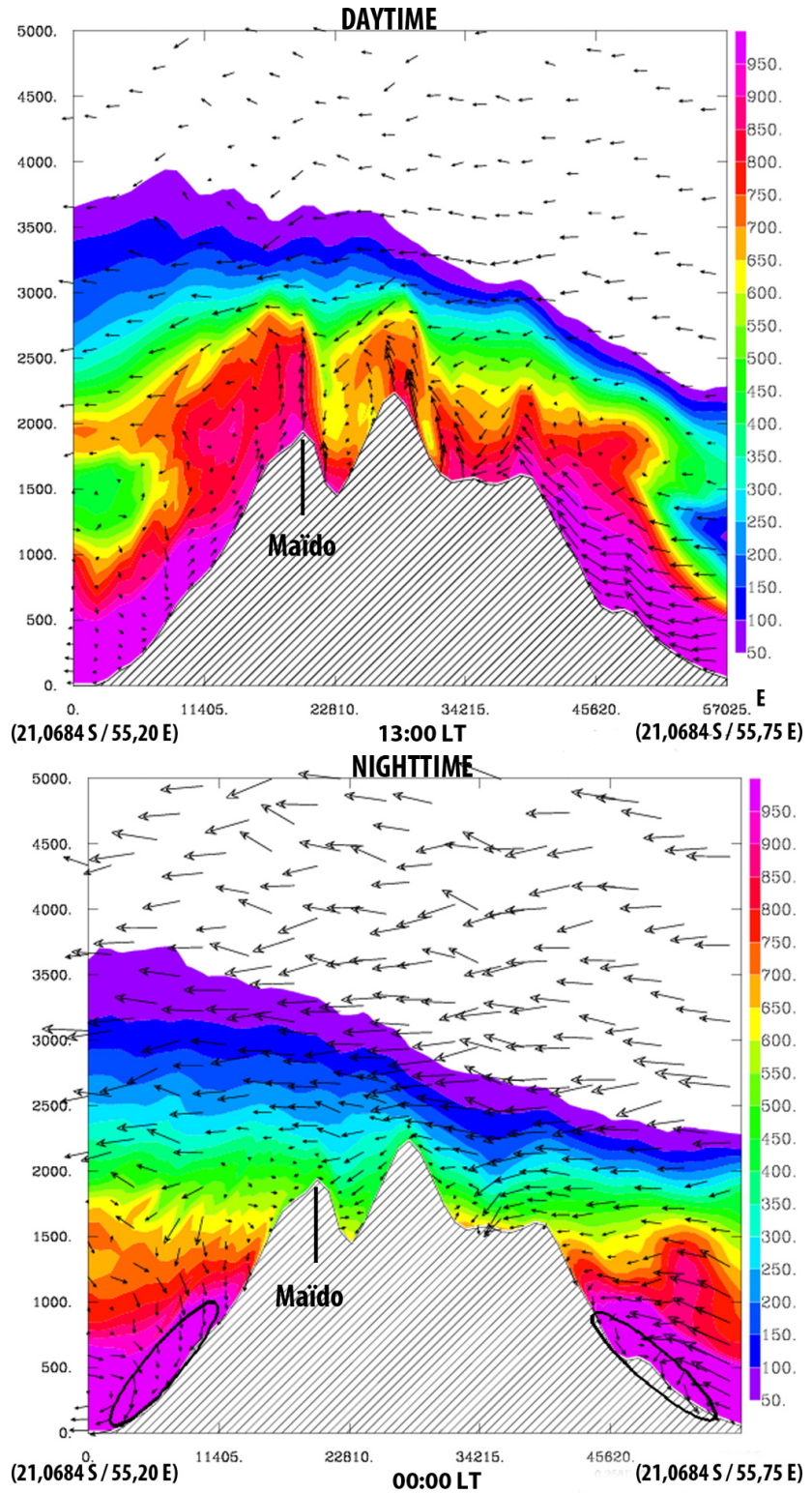

Fig. 10. Simulation ALIZ5 - vertical cross section (W-E, indicated on Fig. 9, top) of the ABL tracer concentration (colorscale in per mil of the concentration in the ABL) at 13:00 LT (top) and 00:00 LT (bottom).

atmosphere, ozone concentration increases with height in the first kilometers above the ground (Fig. 3), an opposite diurnal cycle is expected for ozone concentration (i.e. minimum at daytime, maximum at night), as it was observed at Piton Textor in the south-east of Reunion island (see Sect. 2 and Fig. 2). This phenomenon can be explained by thermallyinduced local wind systems (or at least the thermal influence of the island surface on the general flow making the streamlines converge at daytime to the centre of the island, as showed in simulation ALIZ5, Fig. 6). During daytime, air originating from low levels reaches progressively the sum-

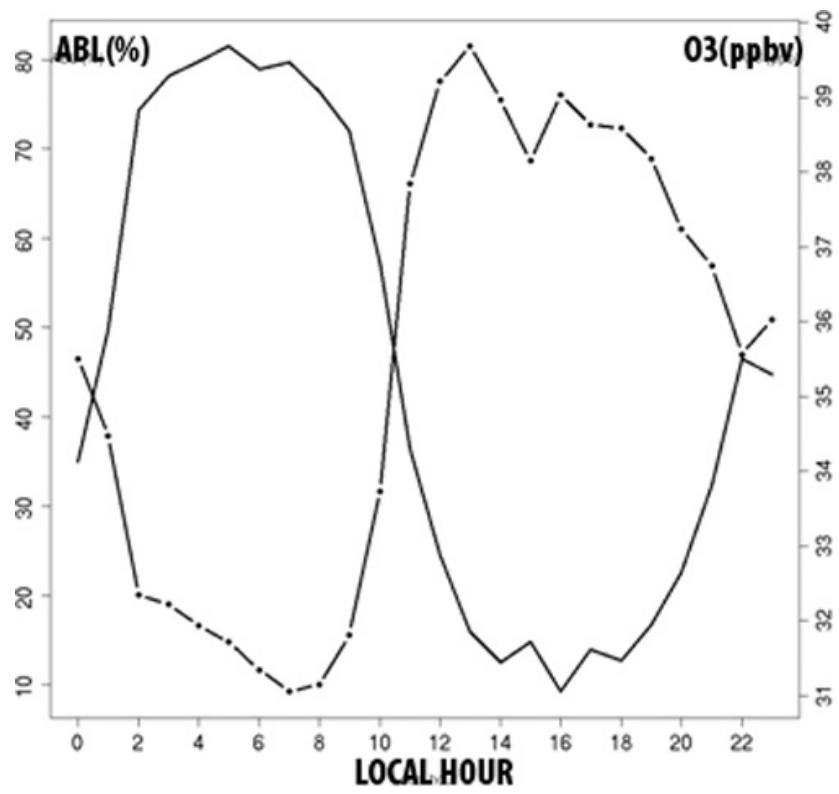

Fig. 11. Diurnal variation of the concentrations in $A B L$ tracer (in percent of the concentration in the $\mathrm{ABL}$, dashed line) and in $\mathrm{O}_{3}$ tracer (solid line, in ppbv) in simulation ALIZ5.

mit of Piton Maïdo under the action of upslope flow (Fig. 10, top). Consequently, the concentration in ABL passive tracer rises to $80 \%$ at the summit of Piton Maïdo during the day (Fig. 11). Ozone-poorer air from lower layers mixes with the ozone-richer air in the free troposphere, and this causes a dilution that reduces the concentration of the pseudo- $\mathrm{O}_{3}$ tracer. At nighttime, the situation reverses: under the action of the downslope flow (Fig. 10, bottom), the concentration of the ABL passive tracer decreases whereas the concentration of the pseudo- $\mathrm{O}_{3}$ tracer rises to its free-tropospheric value.

\subsection{Dispersion of pollutants}

In order to analyze the influence of local pollution sources on ground measurements at Piton Maïdo and discriminate it from background pollution, it was interesting to study the transport of a non-reactive pollutant (e.g. sulfur dioxide which is the main pollutant emitted from various point sources at Reunion Island and is quasi non-reactive on the time scales of our simulations), modeled by the constant emission of a passive tracer from different source points in the model. The source points correspond to pollution sources well identified at Reunion Island (see Fig. 1 and Sect. 3).

\subsubsection{Dispersion of anthropogenic pollutants}

In the numerical experiment ALIZ5, the transport of passive tracers emitted at the surface from the leeward side (POR, DEN, and GOL) are controlled by thermally driven wind systems. In the daytime the tracer emitted from POR is indeed not dispersed offshore but kept on the island by the 

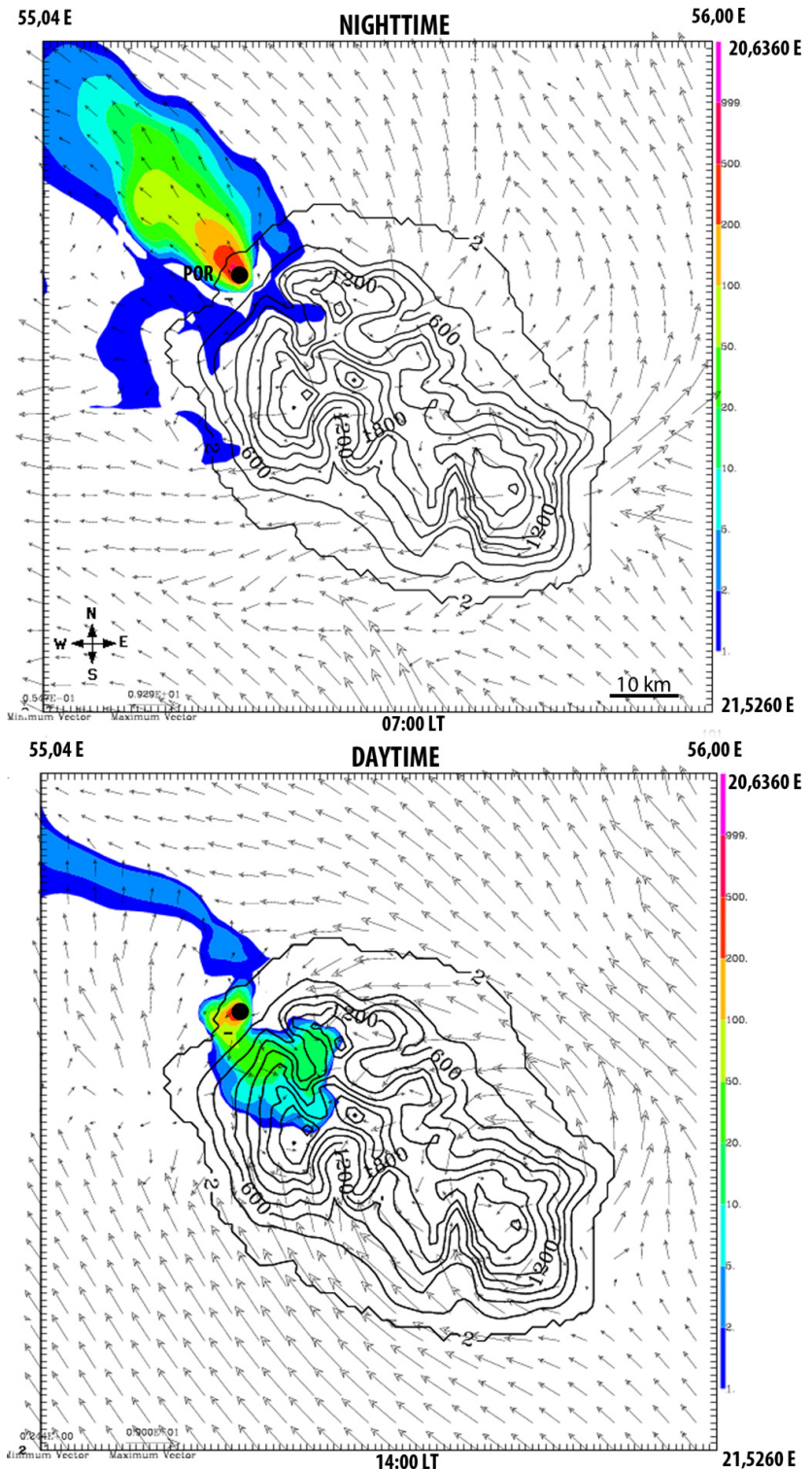

Fig. 12. ALIZ5 - horizontal field of the tracer dilution ratio (per mil of the concentration at emission point) at the first model level above the ground, emitted from POR, at 07:00 LT (top) and 14:00 LT (bottom).

upslope/sea-breeze flow (Fig. 12; similar results - not shown - were obtained for DEN and GOL tracers). These upward winds systems tend to bring polluted air masses from the coast to the Mafate cirque (situated in the west-center; a natural circular depression of volcanic origin surrounded by abrupt walls). These air masses are channeled along canyons such as "Rivière des Galets" for the tracers from DEN and POR and "Rivière St Etienne" for the tracer from GOL. It seems hence likely that a part of this pollution reaches the summit of Piton Maïdo above the Mafate cirque. Thus the simulations highlight channeling effects resulting from topo-

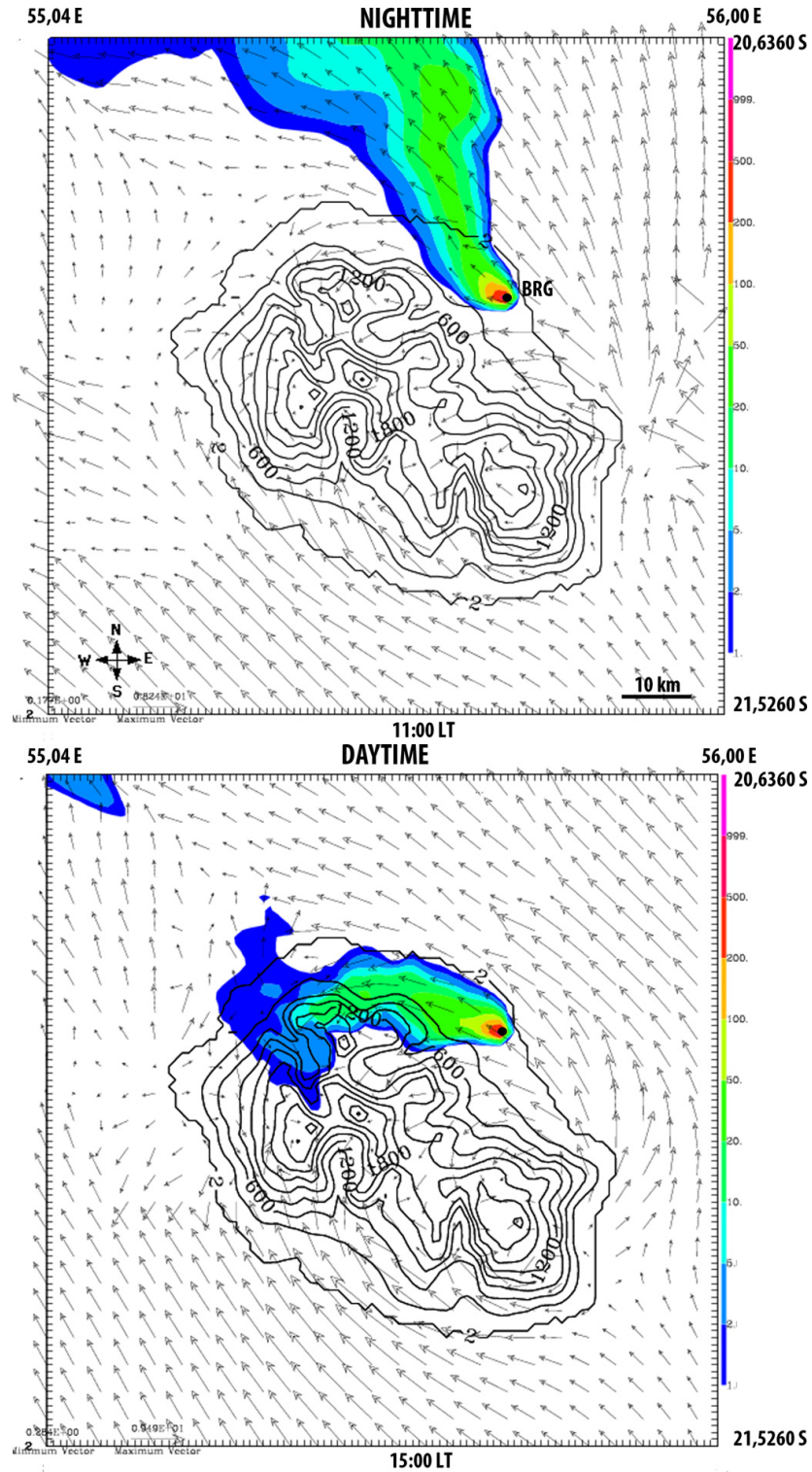

Fig. 13. ALIZ5 - horizontal field of the tracer dilution ratio (per mil of the concentration at emission point) at the first model level above the ground, emitted from BRG, at 11:00 (top) and 15:00 LT (bottom).

graphic features on air masses: In the daytime, valleys and canyons act as chimneys pumping pollutants from lowest layers and transporting them upward, possibly to Piton Maïdo.

In experiment ALIZ5, the weak land-breeze and the tradewind on the northeastern coast scatter the passive tracer emitted from the sugar factory at Bois-Rouge (BRG) over the sea during the night and the morning (Fig. 13). In the daytime, the synoptic flow seems to rather disperse it along the north coast toward St Denis. A part of the plume is kept under the channeling effect of La Rivière des Galets and therefore it is pumped inland owing to the upslope/sea-breeze. In contrast, in the experiment ALIZ10, this passive tracer plume from 


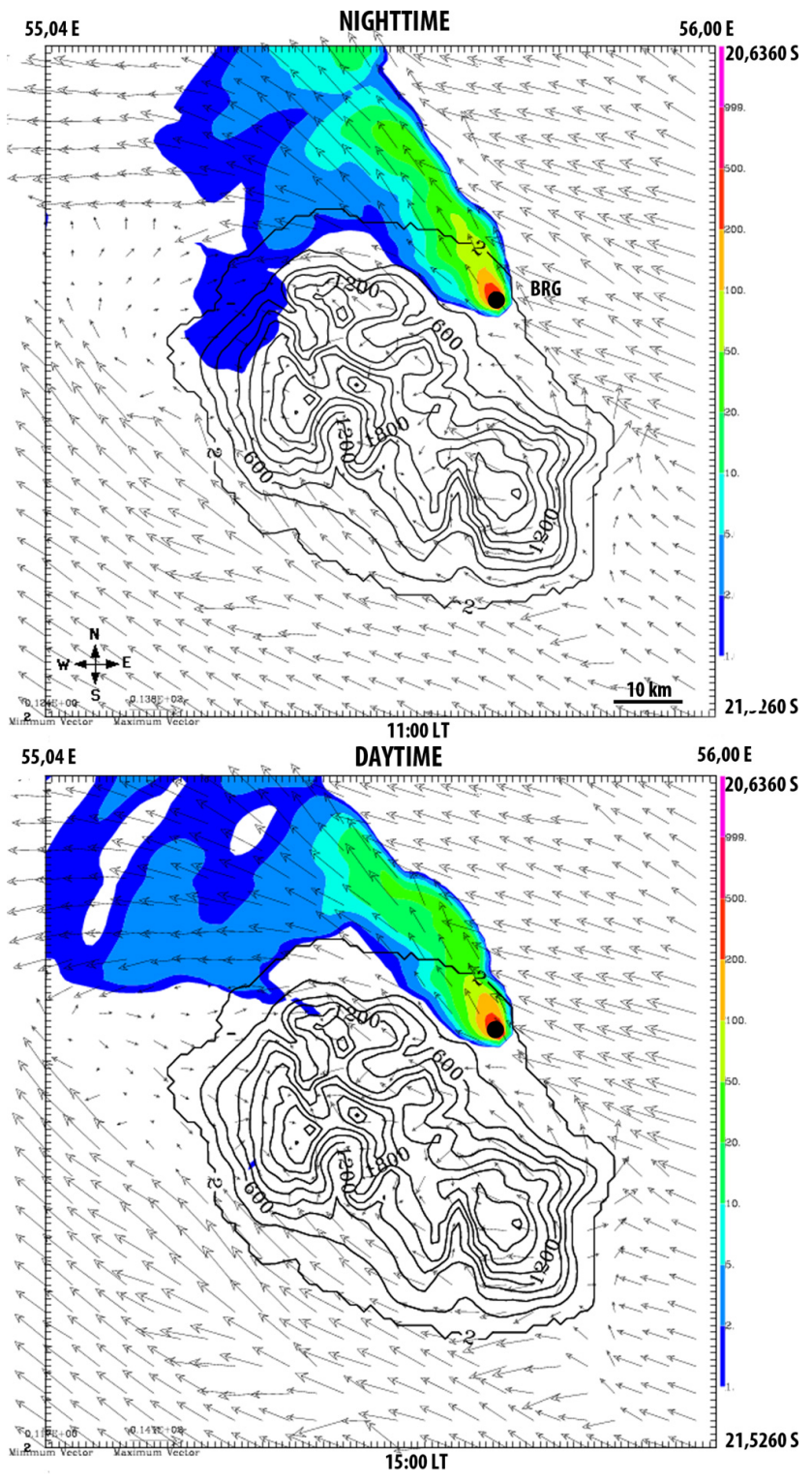

Fig. 14. ALIZ10 - horizontal field of the tracer dilution ratio (per mil of the concentration at emission point) at the first model level above the ground, emitted from BRG, at 11:00 LT (top) and 15:00 LT (bottom).

BRG, is blown by the synoptic flow and dispersed continually northwestward away from the island (Fig. 14).

The numerical experiment ALIZ10 also underlines the effect of vortices in the wake of Reunion Island on the dispersion of pollutants passive tracers. For instance, the passive tracer emitted from the main town St Denis (Fig. 15), is firstly carried offshore north-westerly by the synoptic flux, and then the reverse currents in the wake bring back a part of the passive tracer plume to the western coast. Thus, pollution appears trapped on the leeside coast of the island due to counter-flowing vortices in the wake.
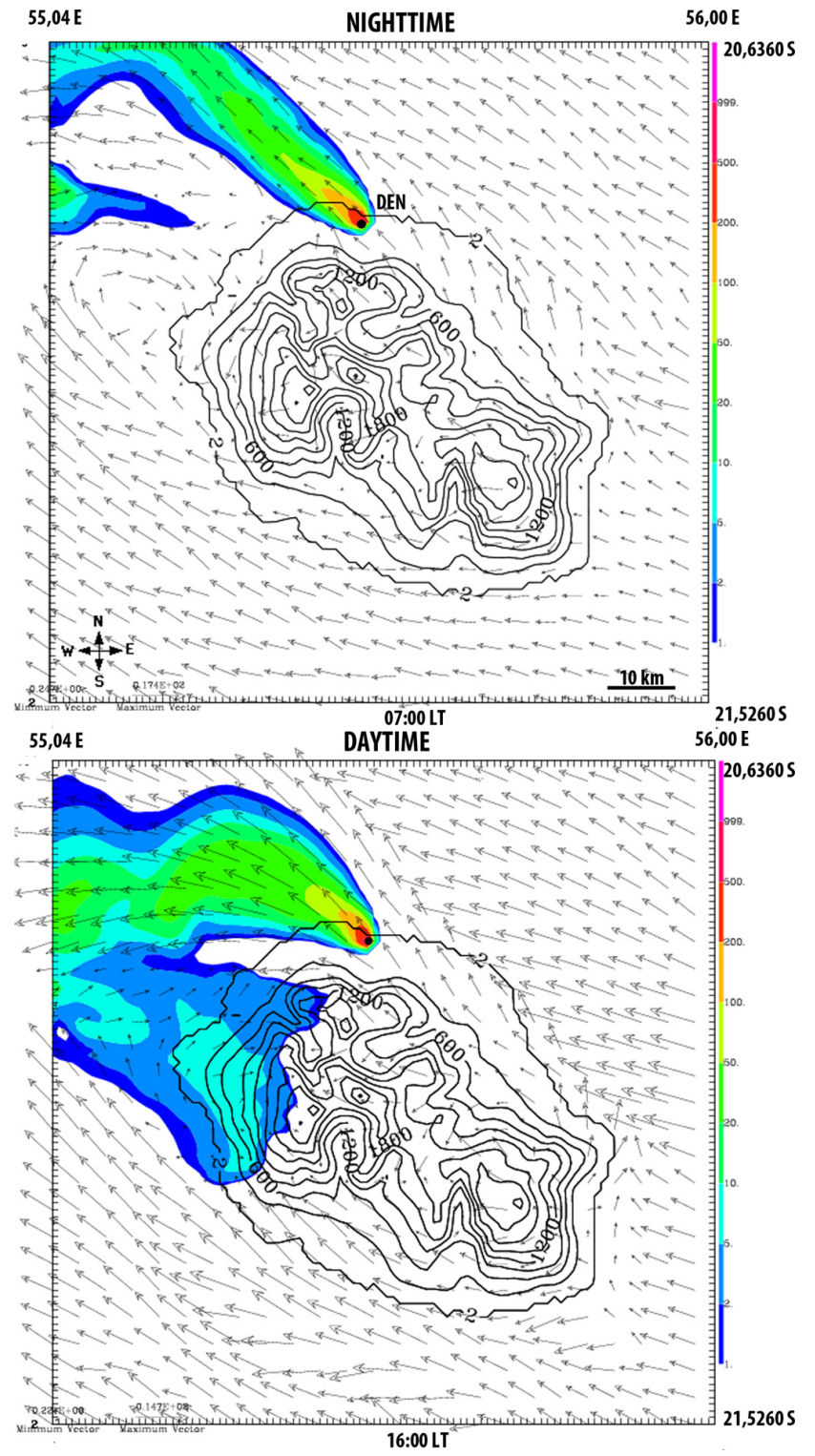

Fig. 15. ALIZ10 - horizontal field of the tracer dilution ratio (per mil of the concentration at emission point) at the first model level above the ground, emitted from DEN, at 07:00 LT (top) and 16:00 LT (bottom).

\subsubsection{Dispersion of the volcanic passive tracer}

Since the site of the future Piton Maïdo observatory is located few ten kilometers downstream from the Fournaise volcano, it could thus become a strategic site to monitor the composition of volcanic plumes on the long term. This is the reason why a passive tracer emitted from the summit of the volcano was released in the model. The numerical experiments enabled to identify possible scenarii of volcanic tracer transport.

The trade-wind disperses the volcanic plume globally northwestward. In simulation ALIZ10, the volcanic plume 

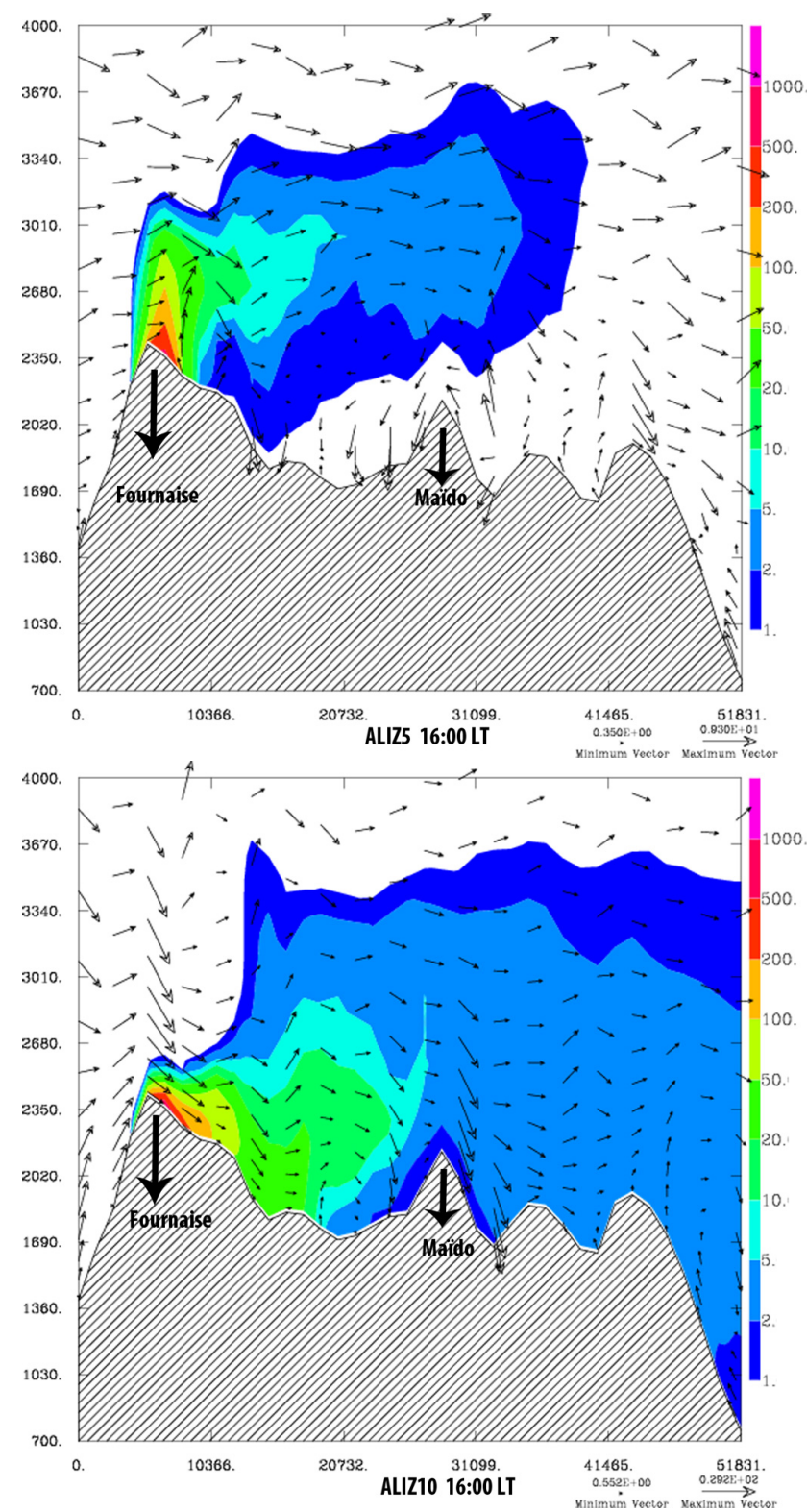

Fig. 16. Vertical cross section Fournaise $\left(21.25^{\circ} \mathrm{S} / 55.76^{\circ} \mathrm{E}\right)-$ Maïdo $\left(21.03^{\circ} \mathrm{S} / 55.32^{\circ} \mathrm{E}\right)$ (indicated on Fig. 9, bottom) of volcanic tracer dilution ratio (per mil of the concentration at emission point) at 16:00 LT (top: ALIZ5, bottom: ALIZ10).

is detectable continually at ground level along a SE-NW line and it seems to be carried horizontally by the synoptic flow. In the numerical simulation ALIZ5 in contrast, the volcanic plume breaks away from the surface area in the afternoon (except in the close vicinity of the volcano) (Fig. 16). Therefore the Piton Maïdo is under the influence of the volcanic plume either continually in the experiment ALIZ10, or only intermittently - during the night - in the experiment ALIZ5 (Fig. 17).

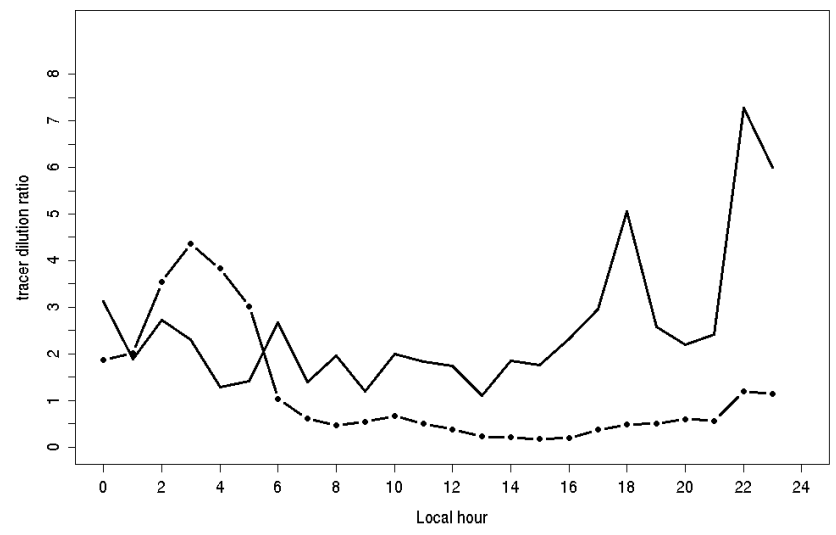

Fig. 17. Evolution of the volcanic passive tracer dilution ratio at Piton Maïdo in 1/1000's of the concentration at emission point PDF (solid line: ALIZ10, dashed line: ALIZ5).

The influence of the volcanic plume at Piton Maïdo thus potentially depends on the strength of the trade-wind. Indeed when the thermal pumping is sufficiently developed in the northwest of the island (ALIZ5), this creates above the relief downstream from the volcano, especially above Piton Maïdo, a cap of clean air from the low levels, especially above Piton Maïdo. The volcanic plume is thus forced to pass over the cap and hence does not impact the observatory (Fig. 16, top). In the numerical experiment ALIZ10, the synoptic wind prevails over thermal pumping and consequently the "cap effect" does not occur (Fig. 16, bottom). In conclusion, it appears that during daytime, the strength of the synoptic wind might be an important parameter controlling the influence of thermal pumping and in turn the detection of the volcanic plume at Piton Maido. This must be confirmed by future continuous $\mathrm{SO}_{2}$ measurements planned at Piton Maïdo.

\section{Conclusion and perspectives}

Atmospheric circulations at local-scale over complex terrain of Reunion Island have been investigated in this paper with a series of high resolution numerical simulations aiming to identify typical mechanisms of local air-pollution transport. Numerical experiments representative of austral winter were carried out in an idealized configuration keeping as main elements the radiative forcing plus a background east-southeasterly synoptic flux of varying strengths, typical of the prevailing trade-wind conditions.

Our simulations highlighted the main following flow patterns, important to understand pollution transport over Reunion Island:

- Flow splitting of the trade-wind occurs around the island. 
- Wind acceleration occurs along the coast lines parallel to the synoptic flux, due to the lateral constriction of the flow by the island and resulting Venturi effect. This acceleration results from a conversion of potential into kinetic energy in the flow, and in turn the top of the marine boundary layer lowers as the flow accelerate.

- Blocking occurs on the island side facing the trade-wind (i.e. its south-eastern part).

- The north-western area on the lee side is screened from the trade-wind by high mountains. This results in a relatively stagnant flow and enables the development of diurnal thermally-induced circulations, combining downslope and land breezes at night, and upslope and sea breezes at daytime.

- Flow splitting is modulated by radiative convergence towards the island at daytime, and divergence from the island at nighttime.

- As result, the flow acceleration (Venturi effect) takes place along the coast with maximum speed at daytime. At night, the trade-wind flow is pushed a few kilometers offshore and the wind speed on the coast is lower.

Consequently, our simulations allowed to identify the following three processes of pollution transport and dispersion:

- Trapping of pollution from the main sources on the coast around the islands occurs on the west coast due to counter-flowing vortices existing in the wake of the island.

- Diurnal transport by anabatic wind systems (upslope and sea breezes) occurs from the western coast in the direction of the Mafate cirque and Piton Maïdo. As consequence for the observatory, minimum concentrations of ozone and maximum concentrations of anthropogenic pollutants are expected at daytime.

- A "cap effect" above reliefs downstream from the volcano, and especially Piton Maïdo, might occur depending on the strength of trade-wind. If the latter are sufficiently weak and allow the development of breezes on the west coast, air pumping from lower layers protects the mountains from the volcanic plume, forced to pass over a "cap" of low-level air clean of volcanic emissions.

In order to corroborate the main findings in a more realistic configuration, the present study has been continued with real case numerical simulations. These were based upon a field campaign and aimed to validate the model and characterize the vertical structure and temporal evolution of the local planetary boundary layer around and inside the island using a mobile LIDAR instrument. This work will be presented in a coming paper.
Acknowledgements. This work was granted access to the HPC resources of IDRIS under the allocation 2007-[0111076] made by GENCI (Grand Equipement National du Calcul Intensif). The authors are grateful to Delphine Ramalingom at the University of Reunion Island, for precious help related to MESONH and the simulations. Ozone sonde and surface data used in this study were provided by Françoise Posny and Jean-Marc Metzger (Laboratoire de l'Atmosphère et des Cyclones, Université de La Reunion) and Chatrapatty Bhugwant (ORA - Observatoire Réunionnais de l'Air).

Topical Editor P. M. Ruti thanks two anonymous referees for their help in evaluating this paper.

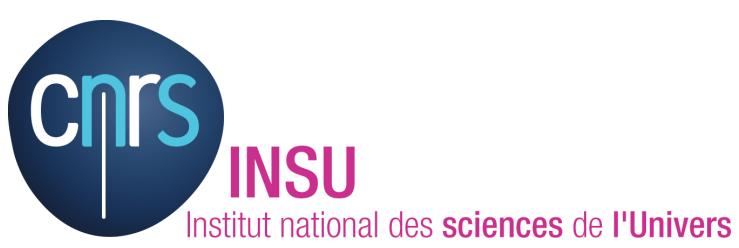

The publication of this article is financed by CNRS-INSU.

\section{References}

Asencio, N., Stein, J., Chong, M., and Gheusi, F.: Analysis and simulation of local and regional conditions for the rainfall over the Lago Maggiore Target Area during MAP IOP 2b, Q. J. Roy. Meteorol. Soc., 129, 565-586, 2003.

Atlas, E. L. and Ridley, B. A.: The Mauna Loa Observatory Photochemistry Experiment: Introduction, J. Geophys. Res., 101, 14531-14541, 1996.

Austin, G. R., Rauber, R. M., Ochs, H. T., and Miller, L. J.: Tradewind clouds and Hawaiian rainbands, Mon. Weather Rev., 124, 2126-2151, 1996.

Baldy, S., Ancellet, G., Bessafi, M., Badr, A., and Lan San Luk, D.: Field observations of the vertical distribution of tropospheric ozone at the island of Reunion (southern tropics), J. Geophys. Res., 101, 23835-23849, 1996.

Baray, J.-L., Leveau, J., Baldy, S., Jouzel, J., Keckhut, P., Bergametti, G., Ancellet, G., Bencherif, H., Cadet, B., Carleer, M., David, C., de Mazière, M., Faduilhe, D., Godin Beekmann, S., Goloub, P., Goutail, F., Metzger, J.-M., Morel, B., Pommereau, J.-P., Porteneuve, J., Portafaix, T., Posny, F., Robert, L., and Van Roozendael, M.: An instrumented station for the survey of ozone and climate change in the southern tropics, J. Environ. Monit., 8, 1020-1028, 2006.

Bhugwant, C., Rivière, E., Keckhut, P., and Leveau, J.: Variability of carbonaceous aerosols, ozone and radon at Piton Textor, a mountain site on Runion island (south-western Indian Ocean), Tellus B, 53(5), 546-563, doi:10.1034/j.16000889.2001.530503, 2001.

Bhugwant, C., Siéja, B., Perron, L., Rivière, E., and Staudacher, T.: Impact régional du SO2 d'origine volcanique induit par l'éruption du Piton de la Fournaise en juin-juillet 2001, Pollution atmosphérique 176, 527-539, 2002.

Bonasoni, P., Stohl, A., Cristofanelli, P., Calzolari, F., Colombo, T., and Evangelisti, F.: Background ozone variations at Mt. Cimone Station, Atmos. Environ., 34, 5183-5189, 2000.

Bougeault, P. and Lacarrère, P.: Parameterization of orographyinduced turbulence in a mesobeta-scale model, Mon. Weather 
Rev., 117, 1872-1890, 1989.

Brighton, P. W.: Strongly stratified flow past three-dimensional obstacles, Q. J. Meteorol. Soc., 104, 289-307, 1978.

Chaboureau, J.-P. and Bechtold, P.: A simple cloud parameterization derived from cloud resolving model data: Diagnostic and prognostic applications, J. Atmos. Sci., 59, 2362-2372, 2002.

Chaboureau, J.-P. and Bechtold, P.: Statistical representation of clouds in a regional model and the impact on the diurnal cycle of convection during Tropical Convection, Cirrus and Nitrogen Oxides (TROCCINOX), J. Geophys. Res., 110, D17103, doi:10.1029/2004JD005645, 2005.

Chen, Y.-L. and Wang, J.-J.: Diurnal variations of surface thermodynamic fields on the island of Hawaii. Mon. Weather Rev., 122, 2125-2138, 1994.

Chevalier, A., Gheusi, F., Delmas, R., Ordóñez, C., Sarrat, C., Zbinden, R., Thouret, V., Athier, G., and Cousin, J.-M.: Influence of altitude on ozone levels and variability in the lower troposphere: a ground-based study for western Europe over the period 2001-2004, Atmos. Chem. Phys., 7, 4311-4326, doi:10.5194/acp-7-4311-2007, 2007.

Chopra, K. P. and Hubert, L. F.: Mesoscale eddies in wake of islands, J. Atmos. Sci., 22, 652-657, 1965.

Cuxart, J., Bougeault, P., and Redelsperger, J. L.: A turbulence scheme allowing for mesoscale and large-eddy simulations, Q. J. Roy. Meteorol. Soc., 126, 1-30, 2000.

De Wekker, S. F. J., Steyn, D. G., and Nyeki, S.: A comparison of aerosol-layer and convective boundary-layer structure over a mountain range during STAAARTE '97, Bound.-Lay. Meteorol., 113, 249-271, 2004.

Eber, L. E.: Upper air and surface wind observations in Project Shower, Tellus, 9, 558-568, 1957.

Fehsenfeld, F. C., Bollinger, M. J., Liu, S. C., Parrish, D. D., McFarland, M., Trainer, M., Kley, D., Murphy, P. C., and Albritton, D. L.: A study of Ozone in the Colorado Mountains, J. Atmos. Chem., 1, 87-105, 1983.

Feng, J. and Chen, Y.-L.: Evolution of katabatic flow on the island of Hawaii during 10 August 1990, Mon. Weather Rev., 126, 2185-2199, 1998.

Gal-Chen, T. and Sommerville, R. C. J.: On the use of a coordinate transformation for the solution of the Navier-Stokes equations, J. Computat. Phys., 17, 209-228, 1975.

Garrett, A. J.: Orographic cloud over the eastern slopes of Mauna Loa volcano, Hawaii, related to insolation and wind, Mon. Weather Rev., 108, 931-941, 1980.

Gheusi, F., Brunner, D., Henne, S., and Stähelin, J.: Influence of small-scale transport on ozone and precursors concentrations at the high-Alpine observatory Jungfraujoch ( $3580 \mathrm{~m}$ asl): a finescale model study. IGAC 10th International Conference, Annecy, France, September 2008.

Hahn, C. J., Merrill, J. T., and Mendonca, B. G.: Meteorological influences during MLOPEX, J. Geophys. Res., 97, 10291-10309, 1992.

Hastenrath, S.: Climate dynamics of the tropics, Kluwer Academy, 1991.

Lafore, J. P., Stein, J., Asencio, N., Bougeault, P., Ducrocq, V., Duron, J., Fischer, C., Héreil, P., Mascart, P., Masson, V., Pinty, J. P., Redelsperger, J. L., Richard, E., and Vilà-Guerau de Arellano, J.: The Meso-NH Atmospheric Simulation System. Part I: adiabatic formulation and control simulations, Ann. Geophys.,
16, 90-109, doi:10.1007/s00585-997-0090-6, 1998.

Leopold, L. B.: The interaction of trade wind and sea breeze, Hawaii, J. Meteor., 6, 312-320, 1949.

Lipps, F. B. and Hemler, R. S.: A scale analysis of deep moist convection and some related numerical calculations, J. Atmos. Sci., 39, 2192-2210, 1982.

Martínez, D., Jiménez, M. A., Cuxart, J., and Mahrt, L.: Heterogeneous nocturnal cooling in a large basin under very stable conditions, Bound.-Lay. Meteorol., 137, 97-113, 2010.

Masson, V., Champeaux, J. L., Chauvin, F., Meriguet, C., and Lacaze, R.: A Global Database of Land Surface Parameters at 1-km Resolution in Meteorological and Climate Models., J. Climate, 16, 161-1282, 2003.

Mendonca, B. G.: Local wind circulation on the slopes of Mauna Loa, J. Appl. Meteor., 8, 533-541, 1969.

Mlawer, E. J., Taubman, S. J., Brown, P. D., Iacono, M. J., and Clough, S. A.: Radiative transfer for inhomogeneous atmospheres: RRTM, a validated correlated-k model for the longwave, J. Geophys. Res., 102D, 16663-16682, 1997.

Moll, H. G.: Die atmosphärische Umströmung Madeiras, Beitraege zur Physik der Atmosphaere, 44, 227-244, 1971.

Morcrette, J.-J.: Radiation and cloud radiative properties in the European centre for medium range weather forecasts forecasting system, J. Geophys. Res., 96, 9121-9132, 1991.

Naja, M., Lal, S., and Chand, D.: Diurnal and seasonal variabilities in surface ozone at a high altitude site $\mathrm{Mt} \mathrm{Abu}\left(24.6^{\circ} \mathrm{N}, 72.7^{\circ} \mathrm{E}\right.$ $1680 \mathrm{~m}$ a.s.1.) in India, Atmos. Environ., 37, 4205-4215, 2003.

Noilhan, J. and Planton, S.: A simple parametrization of land surface processes for meteorological models, Mon. Weather Rev., 117, 536-549, 1989.

Pinty, J. and Jabouille, P.: A mixed-phase cloud parameterization for use in mesoscale non hydrostatic model: simulations of a squall line and of orographic precipitations, Proc. Conf. Of Cloud Physics, Everett, WA, USA, American Meteorological Society, pp 217-220, http://mesonh.aero.obs-mip.fr/mesonh/ dir_publication/pinty_jabouille_ams_ccp1998.pdf, 1998.

Rasmussen, R., Smolarkievicz, P. K., and Warner, J.: On the dynamics of Hawaiian cloud bands: comparison of model results with observations and island climatology, J. Atmos. Sci., 46, 1589-1608, 1989.

Richard, E., Chaboureau, J.-P., Flamant, C., Champollion, C., Hagen, M., Schmidt, K., Kiemle, C., Corsmeier, U., Barthlott, C., and Di Girolamo, P.: Forecasting summer convection over the Black Forest: a case study from the Convective and Orographically induced Precipitation Study (COPS) experiment, Q. J. Roy. Meteorol. Soc., in press, doi:10.1002/qj.710, 2011.

Schroeder, T. A.: Characteristics of local winds in northwest Hawaii, J. Appl. Meteor., 20, 874-881, 1981.

Schroeder, T., Kilonsky, B. J., and Meisner, B. N.: Diurnal variation in rainfall and cloudiness. UHMET Report 77-03, Department of Meteorology, University of Hawaii, 67 pp, 1977.

Smith, R. B. and Grubisic, V.: Aerial observation of Hawaii's wake, J. Atmos. Sci., 50, 3728-3750, 1993.

Smolarkievicz, P. K., Rasmussen, R., and Clark, T. L.: On the dynamics of Hawaiian cloud bands: Island forcing, J. Atmos. Sci., 45, 1872-1905, 1988.

Soler, O.: Atlas climatique de la Réunion, MétéoFrance Réunion, 1997.

Stein, J., Richard, E., Lafore, J. P., Pinty, J. P., Asencio, N., and 
Cosma, S.: High-Resolution Non-Hydrostatic Simulations of Flash-Flood Episodes with Grid-Nesting and Ice-Phase Parameterization, Meteor. Atmos. Phys., 72, 203-221, 2000.

Taupin, F. G., Bessafi, M., Baldy, S., and Brémaud, P. J.: Tropospheric ozone above the southwestern Indian Ocean is strongly linked to dynamical conditions prevailing in the tropics, J. Geophys. Res., 104, 8057-8066, 1999.

Thompson, A. M., Witte, J. C., McPeters, R. D., Oltmans, S. J., Schmidlin, F. J., Logan, J. A., Fujiwara, M., Kirchhoff, V. W. J. H., Posny, F., Coetzee, G. J. R., Hoegger, B., Kawakami, S., Ogawa, T., Johnson, B. J., Vömel, H., and Labow, G.: Southern Hemisphere Additional Ozonesondes (SHADOZ) 1998-2000 tropical ozone climatology 1. Comparison with Total Ozone Mapping Spectrometer (TOMS) and ground-based measurements, J. Geophys. Res., 108(D2), 8238, doi:10.1029/2001JD000967, 2003.
Tsutsumi, Y. and Matsueda, H.: Relationship of ozone and CO at the summit of Mt. Fuji $\left(35.35^{\circ} \mathrm{N}, 138.73^{\circ} \mathrm{E}, 3776 \mathrm{~m}\right.$ above sea level) in summer 1997, Atmos. Environ., 34, 553-561, 2000.

Viane, C., Bhugwant, C., Siéja, B., Staudacher, T., and Démoly, P.: Etude comparative des émissions de gaz volcanique du Piton de la Fournaise et des hospitalisations pour asthme de la population réunionnaise de 2005 à 2007, Revue française d'allergologie, 49, 346-351, 2009.

Zaveri, R. A., Saylor, R. D., Peters, L. K., McNider, R., and Song, A.: A model investigation of summertime diurnal ozone behavior in rural mountainous locations, Atmos. Environ., 29, 1043-1065, 1995.

Zellweger, C., Ammann, M., Buchmann, B., Hofer, P., Lugauer, M., Rüttimann, R., Streit, N., Weingartner, E., and Baltensperger, U.: Summertime NOy speciation at the Jungfraujoch, $3580 \mathrm{~m}$ above sea level, Switzerland, J. Geophys. Res., 105, 6655-6667, 2000.

Zimmermann, L. I.: Atmospheric wake phenomena near the Canary Islands, J. Appl. Meteorol., 8, 896-907, 1969. 